\title{
El conflicto entre Uruguay y Argentina por la jurisdicción del Río de la Plata (1907-1910). Política exterior, imágenes mutuas y sentimiento nacional
}

\author{
Ana María Rodríguez Ayçaguer \\ Universidad de la República, Uruguay
}

Resumen. El artículo analiza el conflicto entre Uruguay y Argentina por el Río de la Plata (1907-1910), a partir de la consulta de documentación inédita no utilizada hasta el momento, en particular la correspondencia confidencial entre el canciller argentino Estanislao S. Zeballos y el representante de ese país en Montevideo. El trabajo muestra cómo afloran las imágenes mutuas al calor del conflicto: en el caso uruguayo, la Argentina fuerte que abusa del débil; en el caso argentino, los gobernantes uruguayos, políticos inexpertos y poco realistas, a quienes manipula la diplomacia brasileña. El trabajo plantea dos hipótesis: en primer lugar, que el conflicto contribuyó con el proceso de construcción del sentimiento nacional en ambos países; en segundo lugar, que la retórica de la confraternidad que aflora, aquí y allá, en medio de la dureza de los enfrentamientos, muestra la dificultad de construir la imagen de "el otro" cuando ese "otro" tiene tantas cosas en común con nosotros.

Palabras claves: jurisdicción del Río de la Plata - sentimiento nacional - Argentina - Uruguay

\footnotetext{
Abstract. The article anlizes the dispute between Uruguay and Argentine about the jurisdiction of the River Plate (1907-1910), using unpublished documents that have not been used so far by historians, especially the confidential correspondence between de Argentine Minister for Foreign Affairs, Estanislao S. Zeballos, and the Argentine ambassador in Montevideo, Alejandro Guesalaga. The work shows how mutual images arise in the heat of conflict: in Uruguay, the vision of the strong Argentine abusing the weak. In Argentine, the perception of Uruguayan government as a group of inexperienced and unrealistic politicians, manipulated by Brazilian
} 
diplomacy. Article raises two hypotheses: first, that the the border conflict contributed to the process of building the national sentiment in both countries; and second, that the rhetoric of brotherhood that emerges here and there, amid the harshness of the dispute, shows the difficulty of building the image of "the other" when that "other" has so many things in common with us.

Key words: River Plate jurisdiction - national identity - Argentine - Uruguay

\section{Introducción}

Cuando en 1910 Argentina conmemoró el Primer Centenario de la Revolución de Mayo, las relaciones con Uruguay venían de más de dos años de serias divergencias entre el gobierno argentino presidido por José Figueroa Alcorta y el uruguayo encabezado por el Dr. Claudio Williman, por el complejo tema de la jurisdicción del Río de la Plata. La inminencia de aquella conmemoración sirvió para apurar un arreglo amistoso -el Protocolo Ramírez-Sáenz Peña, firmado en Montevideo el 5 de enero de 1910- que permitió que Uruguay estuviera presente en las grandes celebraciones que tuvieron lugar en el país vecino durante ese año. En mayo de 2010, en tiempos del Bicentenario, las relaciones entre Uruguay y Argentina nuevamente pasaban por un mal momento; esta vez el diferendo estaba relacionado con el Río Uruguay, el otro gran límite natural entre ambos países. Para quien escribe, el recuerdo de lo sucedido un siglo atrás fue inevitable y ello sirvió de disparador para el inicio de una investigación sobre el primer conflicto, en la que he venido trabajando desde hace varios años y de cuyos resultados se nutre este trabajo.

Debo advertir que no intentaré aquí realizar un análisis en profundidad del conflicto y de las negociaciones que condujeron a su momentánea solución, imposible de abordar en un trabajo tan acotado. Mi objetivo es realizar una aproximación a dicha coyuntura, buscando registrar las imágenes mutuas que la disputa limítrofe puso en evidencia. Partimos de asumir que las visiones del otro forman parte del "utillaje" mental con que se alimenta la toma de decisiones y que éstas, a su vez, actúan sobre dichas percepciones, a veces reafirmándolas. ${ }^{1}$

1 Entre la bibliografía que ilustra sobre el punto, un ejemplo de la riqueza que puede ofrecer el análisis de estas imágenes, formulado desde diferentes perspectivas, en: IRIYE, Akira (Editor). Mutual 
A comienzos del siglo XX, Argentina y Uruguay, países vecinos y unidos por una larga historia de luchas en común, por un mismo idioma y por fuertes vínculos de todo tipo, se encontraban en una etapa avanzada del proceso de construcción de identidades nacionales que se venía procesando en ambos países del Río de la Plata, por lo menos desde el último cuarto del siglo XIX.

La investigación permite percibir cómo, en un marco de enfrentamiento y de exaltación de los sentimientos patrióticos, las imágenes y representaciones mutuas muestran el debilitamiento de las expresiones de confraternidad, las que son matizadas -y a veces sustituidas- por imágenes de tono negativo. Simultáneamente, pueden percibirse indicios del fortalecimiento del sentimiento de identidad nacional. En este sentido, puede plantearse como una primera hipótesis -sujeta a mayor comprobación- que el conflicto limítrofe contribuyó a fortalecer ese proceso de construcción del sentimiento nacional. La evidencia reunida nos permite aventurar una segunda hipótesis: las expresiones que apelan a la confraternidad entre ambos pueblos queafloran, aquí y allá, en medio de la dureza de los enfrentamientos muestran la dificultad de construir la imagen de "el otro" cuando se trata de aquellos con los que se tiene muchas cosas en común.

El grueso de la investigación se centra en el análisis de documentación inédita, tanto argentina como uruguaya, la que ha sido complementada con la consulta -muy acotada- de prensa periódica de ambos países. En especial, creemos necesario destacar, por su riqueza y por ser la primera vez que dicha documentación se abre a la consulta, la correspondencia "reservada" y "confidencial" intercambiada entre el canciller argentino Estanislao S. Zeballos y el representante diplomático argentino en Montevideo, Alejando Guesalaga, que se encuentra en el Archivo Histórico del Ministerio de Relaciones Exteriores y Culto de la República Argentina (AMREC). ${ }^{2}$ Para el caso uruguayo, sin embargo, la papelería diplomática referida al conflicto está desaparecida, a excepción de unas pocas cartas intercambiadas entre el Ministro del Uruguay en Buenos Aires, Eduardo Acevedo Díaz, y el canciller uruguayo Jacobo

images. Essays in American-Japanese Relations. Harvard University Press, 1975.

2 Esta documentación se encuentra en el fondo Dirección de Límites y Fronteras (DILYF), que está cerrado a la consulta de los investigadores. Debo agradecer al personal de dicho Archivo, en particular a la funcionaria de sala Alba Lombardi y a la Directora del Archivo Histórico, Julia Scarenci, por la excelente disposición con que atendieron mis consultas y en especial, por el apoyo recibido para tramitar la desclasificación de dicha documentación. 
Varela Acevedo, que consultamos en el Archivo Histórico-Diplomático del Ministerio de Relaciones Exteriores de Uruguay (AMREU). Hemos podido reconstruir los pormenores de las negociaciones y las razones que están detrás de las decisiones adoptadas por el gobierno uruguayo en torno al tema, gracias a la documentación existente en el Archivo del Presidente Claudio Willimany el Archivo de Juan E. Pivel Devotoque se conservan en el Archivo General de la Nación de Uruguay (UY-AGN), así como en el Archivo de Antonio Bachini(sucesor de Varela Acevedo al frente de la Cancillería uruguaya) que se conserva en el Museo Histórico Nacional de Uruguay (MHN). A estos fondos, debemos sumar el Archivo del Dr. José Figueroa Alcorta, del Archivo General de la Nación Argentina (AGNA), cuya revisión apenas hemos iniciado. La investigación incluye asimismo prensa uruguaya del período, que proviene en todos los casos de los fondos del AMREC, fruto del relevamiento que de la misma realizaba el Ministro Guesalagapara informar al canciller Zeballos; así como prensa argentina recopilada en la Cancillería de ese país.

Entre la bibliografía que se ha ocupado del conflicto y sus protagonistas -con diversosenfoques y desigual profundidad- no hay trabajos que se basen en fuentes primarias y con investigaciones realizadas en los archivos de ambos países.Tampoco encontramos en ellos abordajes que exploren el tema de las "imágenes mutuas". En el caso argentino, la mayor parte de los estudios se centran en lafigura del canciller Estanislao S. Zeballos y su política para enfrentar los planes de la diplomacia brasileña, encabezada por el Barón de Río Branco, hacia el Río de la Plata, no existiendo un análisis de la postura uruguaya que utilice fuentes de este origen, ya sea primarias o secundarias. ${ }^{3}$ La bibliografía brasileña que analiza ese período de las

\footnotetext{
3 En términos generales, la producción argentina sobre la historia de las relaciones exteriores de ese país se ocupa muy poco de las relaciones con Uruguay. Para el período que estudiamos, la principal excepción es la obra dirigida por Andrés Cisnero y Carlos Escudé (ESCUDÉ, Carlos y CISNEROS, Andrés. Historia General de las Relaciones Exteriores Argentinas, Buenos Aires, CARI, 15 vols. El conflicto es analizado sucintamente en el T. VII, Capítulo 38.http://www.argentinarree.com/historia.htm ), sin recurrir a la correspondencia diplomática y basándose casi totalmente en los trabajos de Roberto Etchepareborda, historiador, diplomático y principal especialista en Zeballos y su política exterior. Los trabajos de este autor, en especial su ya clásico análisis (ETCHEPAREBORDA, Roberto. Zeballos y la política exterior argentina. Buenos Aires, Pleamar, 1982) contienen valiosa información, aunque no dejan de trasmitir una visión apologética de Zeballos y su política. Algo similar sucede con el aporte de Nora L. SIEGRIST de GENTILE ("Política exterior argentina durante la Presidencia Figueroa Alcorta (1906-1910). El Memorandum Secreto del Doctor Estanislao S. Zeballos",en SIEGRIST de GENTILE, Nora L., GIRBAL de BLACHA, Noemí y BRAILOVSKY, Antonio Elio. Tres estudios argentinos. Buenos Aires, Editorial Sudamericana, 1982). Enfoques más recientes aportan miradas más críticas y diversas, como los trabajos de Pablo LACOSTE ("Chile y Argentina al borde la guerra (1881-1902)”, en Anuario del CEH, $\mathrm{N}^{\circ}{ }_{1}$, Año ${ }^{\circ}$, Córdoba, 2001, pp. 301-328.; y "Estanislao Zeballos y la política exterior Argentina con Brasil y Chile", en: Revista Confluencia, año 1, número 2, primavera 2003, Mendoza, Argentina, pp. 107-128). Si bien éstos no se ocupan del conflicto
} 
relaciones argentino-brasileñas, también se centra en el enfrentamiento entre los mencionados protagonistas y sus políticas en un contexto de tensión y planes armamentistas, constituyendo, al igual que en el caso de la producción argentina, un aporte para la comprensión del conflicto limítrofe uruguayo-argentino en el contexto regional. ${ }^{4}$

En el caso de la producción uruguaya (o de historiadores extranjeros que trabajan sobre historia uruguaya) las limitaciones son similares. No hay un estudio que se dedique específicamente a analizar el conflicto limítrofe en todas sus facetas y en las obras que han abordado el tema, el acceso a fuentes primarias es limitado (una excepción es la obra del hijo del PresidenteWilliman);aunque algunos autores incorporan testimonios éditos de contemporáneos y Eduardo Acevedo, creemos, testimonios orales a los que tuvo acceso aunque no los menciona. ${ }^{5}$

con Uruguay, aportan elementos de interés para comprender la política exterior impulsada por Zeballos y el pensamiento del canciller argentino. El libro sobre Zeballos compilado por Sandra FERNÁNDEZ y Fernando NAVARRO (Scribereestagere. Estanislao Zeballos en la vorágine de la modernidad argentina. La Quinta Pata\& Camino Ediciones, Rosario, Argentina, 2011), ofrece múltiples miradas para analizar la polifacética personalidad de Zeballos, aunque no aporta elementos nuevos para nuestro tema ya que el abordaje de su gestión como canciller se basa en la bibliografía existente. Por su parte, el libro de Alfredo DÍAZ de MOLINA sobre el Presidente del período (José Figueroa Alcorta. De la oligarquía a la democracia. 1898-1928. Buenos Aires, Editorial Plus Ultra, 1979, pp. 170-171) apenas se ocupa del conflicto y lo hace con algún error.

$4 \mathrm{Al}$ respecto, ver: BUENO, Clodoaldo. "O rearmamento naval brasileiro e a rivalidade BrasilArgentina em 1906-1908”, en Historia, v. 1, pp. 21-35, Sao Paulo, 1982; DORATIOTO, Francisco. $O$ Brasil no Rio da Prata (1822-1994). $2^{\text {a }}$ ed., Brasilia, FUNAG, 2014, pp. 68-94.

5 La bibliografía centrada en la historia uruguaya incluye en primer lugar a Eduardo ACEVEDO, que en el T. V de sus Anales Históricos (Barreiro y Ramos, Montevideo, 1934) aborda la política internacional del Presidente Williman, y dedica varias páginas al conflicto con Argentina, sobre el que está bastante bien informado (aunque también, como veremos, omite intencionalmente alguna información). Su relato ha sido retomado por la mayoría de los autores. El Arq, José Claudio WILLIMAN, hijo del Presidente, publicó un extenso libro (El Dr. Claudio Williman. Su vida pública. Montevideo, Talleres Gráficos "Prometeo", 1957), en el que se ocupa del conflicto con Argentina, utilizando documentos pertenecientes al archivo de su padre. Entre los aportes al tema de la historia de los límites del Río de la Plata, hay que destacar el papel del historiador y político Juan E. PIVEL DEVOTO, que reunió en una publicación una serie de artículos suyos sobre el conflicto, en la que incluía documentos, algunos de los cuales ya habían sido dados a conocer en el libro de J.C. Williman (El Río de la Plata. Cuadernos de Marcha $\mathrm{N}^{\circ}$ 20, Montevideo, diciembre 1968). En 1973, en su condición de senador, hizo una exposición en la Cámara alta sobre la historia de los límites del Río de la Plata, la que sería luego recogida en un libro publicado por dicha Cámara. (Historia de los límites del Río de la Plata. Islas Martín García y Timoteo Domínguez. Montevideo, Cámara de Senadores, 1973). Milton VANGER, en el T. 2 de su obra sobre José Batlle y Ordóñez (El país modelo. José Batlle y Ordóñez. 1907-1915. Montevideo, Editoriales ARCA y Banda Oriental, 1983) analiza la presidencia de su sucesor, Claudio Williman, y se ocupa del conflicto, aportando documentación que demuestra el apoyo de José Batlle y Ordóñez a la postura del Presidente Williman durante el conflicto. En 1981 Dante TURCATTI publicó un libro sobre la política exterior del batllismo (El equilibrio difícil. La política internacional del Batllismo. Montevideo, Ed. ARCA-CLAEH, 1981), trabajo breve pero pionero, que aborda el tema basándose en E. Acevedo, y fuentes éditas. José Pedro BARRÁN y Benjamín NAHUM, en el T. 2 de su obra sobre el batllismo, se ocupan brevemente del conflicto, a propósito del papel que en el mismo jugó la postura británica sobre los derechos jurisdiccionales en el Río de la Plata. Su análisis se basa en la información que aportan Eduardo Acevedo y los informes de los representantes diplomáticos británicos en el Uruguay. (Batlle, los estancieros y el imperio 
En lo atinente a los procesos de construcción de nacionalidad, para el caso argentino resulta fundamental el trabajo de Lilia A. Bertoni ${ }^{6}$, investigación amplia que ofrece una visión comprensiva de ese movimiento desarrollado con fuerza a partir del último cuarto del siglo XIX, queexperimentó una aceleración en el período señalado, motivada por los temores generados por la inmigración masiva y sus consecuencias sobre la identidad nacional y la soberanía del país. Su trabajoresulta clave para comprender la mentalidad de uno de los protagonistas centrales del conflicto, el canciller argentino Estanislao S. Zeballos, uno de los constructores del relato histórico en ese país y pieza clave en la creación del nacionalismo territorial argentino que soñó con la reconstrucción del Virreinato. Sobre este último aspecto, revisten particular interés los aportes de Pablo Cavaleri y Carla Lois. ${ }^{7}$

También en Uruguay la necesidad de incluir a los inmigrantes pesó en el esfuerzo de construcción del sentimiento de identidad nacional. En la bibliografía uruguaya sobre el tema no existe una obra que, por sí sola, reúna las características de la de L. Bertoni. No obstante, existen múltiples trabajos que se ocupan del tema, muchos de ellos centrados en lo que fue el proceso de reivindicación de la figura de

británico Tomo 2: Un diálogo difícil. Montevideo, Ed. Banda Oriental, 1981, pp. 188-191). Enrique AROCENA OLIVERA, (Evolución y apogeo de la diplomacia uruguaya. 1828-1948. Montevideo, Imp. Palacio Legislativo, 1984). de formación jurídica, aborda el tema de los límites del Río de la Plata y dedica unas páginas al conflicto con Argentina. Cita a Eduardo Acevedo -aunque lo usa muy pocopero omite la consulta de bibliografía ya disponible, renunciando así a insertar el conflicto diplomático en su contexto histórico. En fecha bastante más reciente Clarel DE LOS SANTOS FLORES se ocupa brevemente del conflicto en un avance de investigación centrado en las negociaciones con Brasil para la firma del Tratado de Rectificación de Límites (Soberanía e identidad nacional en el Uruguay del novecientos. Incidencias regionales y nacionales en la gestación del Tratado de Rectificación de Límites entre Uruguay y Brasil en 1909. Montevideo, UdelaR, FHCE, 2010.http://www.fhuce.edu.uy) ubicando las mismas en la coyuntura regional. Allí señala la importancia que tuvo dicho tratado en las negociaciones relacionadas con el conflicto limítrofe con Argentina. Como último antecedente debo incluir una ponencia de mi autoría: RODRÍGUEZ AYÇAGUER, Ana María, "El precio de la paz. La diplomacia argentina y la utilización de la 'amenaza' de la guerra civil para presionar al gobierno de Claudio Williman durante el conflicto por la jurisdicción del Río de la Plata (1907-1910)", presentada en las IV Jornadas de Historia Política, FCS, Montevideo, julio 2013.

6 BERTONI, Lilia Ana. Patriotas, cosmopolitas y nacionalistas: la construcción de la nacionalidad argentina a fines del siglo XIX. Buenos Aires, FCE, 2001.

7 CAVALERI, Paulo. La restauración del Virreinato. Orígenes del nacionalismo territorial argentino. Buenos Aires, Universidad Nacional de Quilmes, 2004; LOIS, Carla. "Técnica, política y 'deseo territorial' en la cartografía oficial de la Argentina (1852-1941)”, en: Scripta Nova. Revista electrónica de Geografía y Ciencias Sociales., Universidad de Barcelona, Vol. X, núm. 218 (52), agosto 2006. Disponible en http://www.ub.edu/geocrit/sn/sn-218-52.htm. [Consulta: 11 de noviembre 2015]. Esta última autora, refiriéndose a la primera vez que fue designado Ministro de Relaciones Exteriores (1889), recuerda que Zeballos, "que había fundado el Instituto Geográfico Argentino en 1879, estaba particularmente familiarizado tanto en los temas limítrofes como en asuntos cartográficos. Considérese sintomático de su perfil el hecho de que a su llegada a la cancillería ordenó la reorganización de la mapoteca y la elaboración de un catálogo de mapas; y encargó esta tarea al ingeniero geógrafo Carlos Beyer". 
José Artigas y su elevación a la condición de "héroe máximo", como parte de la elaboración de un "relato de los orígenes" que pudiese ser aceptado por todos. ${ }^{8}$

El presente trabajo se organiza en torno a dos apartados. En el primero presentaremos el desarrollo del conflicto limítrofe en forma muy acotada, procurando ofrecer la información imprescindible para ubicar en el contexto las evidencias que se ofrecen en la segunda parte. En el apartadosiguiente abordaremos el tema de las imágenes mutuas que el conflicto puso en evidencia; allí haremos algunas precisiones en relación con el "utillaje" mental de algunos protagonistas, nos referiremos a la relación de éstos con la prensa yfinalmente, daremos cuenta de las evidencias recogidas en relación con la exaltación de los sentimientos patrióticos y el rol jugado en aquella coyuntura por algunos de los constructores de una historia nacional en Uruguay.

\section{El conflicto entre Uruguay y Argentina por la jurisdicción del Río de la Plata (1907-1910)}

La situación de indefinición en los límites en el Río de la Plata había sido -y sería por mucho tiempo más- motivo de frecuentes roces y dificultades entre ambos países ribereños. Pero entre agosto de 1907 y abril de 1908 ocurrieron tres hechos que provocaron una grave y prolongada situación de tensión entre Uruguay y Argentina: el decreto de pesca aprobado por el gobierno uruguayo en 1907, el naufragio del vapor "Constitución"acaecido inmediatamente después y las maniobras realizadas por la escuadra argentina en aguas de "jurisdicción uruguaya"en abril de 1908.

$8 \mathrm{Al}$ respecto, ver: Juan E. PIVEL DEVOTO, De la leyenda negra al culto artiguista. [1950-1951] Montevideo, Biblioteca Artigas, Colección de Clásicos Uruguayos, Volumen 171, 2004; Ana FREGA, "La construcción monumental de un héroe", Humanas 18/1-2. Porto Alegre, 1995, pp. 121-149. (el artículo fue reeditado, con el mismo título, en MUSEO HISTÓRICO NACIONAL. Un simple ciudadano, José Artigas. Montevideo, 2014); Carlos DEMASI, “La construcción de un 'héroe máximo': José Artigas en las conmemoraciones uruguayas de 1911", Revista Iberoamericana, Vol. LXXI, Núm. 213, Octubre-Diciembre 2005, pp.1029-1045; y La lucha por el pasado: historia y nación en Uruguay (1920-1930. Montevideo, Ediciones Trilce, 2004; Ariadna ISLAS, "Límites para un Estado. Notas controversiales sobre las lecturas nacionalistas de la Convención Preliminar de Paz de 1828", en: Ana Frega (coord.), Historia regional e independencia del Uruguay. Proceso histórico y revisión crítica de sus relatos. Montevideo, Ed. Banda Oriental, 2009, pp. 169-216; Tomás SANSÓN CORBO. El espacio historiográfico rioplatense y sus dinámicas (Siglo XIX). La Plata, Instituto Cultural de la Provincia de Buenos Aires, 2011. Por último queremos destacar los restantes trabajos que integran -junto al ya citado de Ana Frega- el catálogo publicado por el Museo Histórico Nacional: Ariadna ISLAS, "Historias, visiones, versiones con motivo de una conmemoración"; Ernesto BERETTA y Fernanda GONZÁLEZ (con la colaboración de Mirtha Cazet), "Un simple ciudadano José Artigas"; y Laura MALOSETTI COSTA, "Artigas: imagen y palabra en la construcción del héroe". (MUSEO HISTÓRICO NACIONAL. Un simple ciudadano, José Artigas. Montevideo, 2014). 
El decreto de pesca. El primer detonante del conflicto fue la aprobación por parte del gobierno uruguayo de un decreto autorizando la pesca con redes de arrastre (o "bou") en el Río de la Plata. La resolución, de fecha 3 de agosto de 1907, autorizaba la pesca por dicho procedimiento en las aguas del Río de la Plata, afuera de las cinco millas de la costa uruguaya y hasta la mitad del río. El decreto provocó una fuerte reacción en la prensa argentina que denunció los perjuicios que el mismo acarrearía para la naciente industria de pesca argentina. Los pescadores artesanales uruguayos, a quienes la pesca por arrastre perjudicaba y que además tenían en Buenos Aires su principal mercado, se opusieron a la medidaargumentando que no había suficientes estudios para saber si el empleo de dichas redes podía aparejar una reducción de las especies en las aguas del Río de la Plata. Pero la reacción más fuerte fue la del gobierno argentino, en particular del canciller Estanislao S.Zeballos, que consideró "gravísimo" el decreto, instruyendo al representante argentino en Montevideo para formular reservas. La gravedad estaba dada, según expresó, porque sin consulta previa y sin ningún instrumento jurídico que determinara la jurisdicción de cada país sobre las aguas del Río de la Plata, el gobierno uruguayo había adoptado una medida que daba por sentado que la jurisdicción uruguaya llegaba hasta la mitad del río. ${ }^{9}$

El Ministro argentino en Montevideo recibió instrucciones para presionar al gobierno uruguayo, instándolo a dar marcha atrás. Guesalagaplanteó los reclamos al canciller uruguayo Jacobo Varela Acevedo, a quien consideraba demasiado joven y falto de experiencia para ocupar el cargo, además de excesivamente impulsivo y deseoso de protagonismo, opinión que era compartida por el canciller Zeballos. Cabe señalar que -como veremos en el próximo apartado- el "utillaje" mental de ambos funcionarios argentinos distaba bastante de la mentalidad del elenco batllista, del que formaba parte Varela Acevedo, lo que no contribuyó a facilitar el diálogo.

Siguiendo instrucciones de Zeballos, Guesalagaformuló las reservas a "título personal" -no hubo una reclamación por escrito- pasando luego, por indicación de

9 Telegrama cifrado de Zeballos a Guesalaga, Buenos Aires, 6 de agosto de 1907. AMREC, DILYF, Caja 3, carpeta 43, folios.20-22. [En adelante, abreviados: C, c. fs.] La correspondencia que citamos entre el Canciller Estanislao Zeballos y el Ministro en Montevideo, Alejandro Guesalaga, está rotulada, en casi todos los casos, como "confidencial" y/o "reservada". Por razones de espacio no lo indicamos al dar las referencias. La gran mayoría de las comunicaciones son notas, y hay también algunos telegramas. En el caso de las notas que envía Guesalaga, en su totalidad son notas manuscritas. Las notas de Zeballos por lo general están dactilografiadas. 
Zeballos, a advertir al gobierno uruguayo del peligro de que lanchas pescadoras avanzasen hacia la mitad del Río porque podía producirse algún incidente con buques de guerra argentinos que patrullaban la zona. Y culminaron con la amenaza de la inminente aprobación de un decreto del gobierno argentino prohibiendo la importación de pescado desde Uruguay para proteger a la incipiente industria pesquera argentina. Las gestiones argentinas surtieron efecto y el 9 de agosto, a menos de una semana de aprobado el decreto, el gobierno uruguayo dio marcha atrás y dispuso la suspensión de su aplicación, argumentando que debían realizarse mayores estudios sobre los eventuales perjuicios que aquel sistema de pesca pudiese ocasionar. ${ }^{10}$ La medida fue festejada como una victoria por el canciller Zeballos, pero muy mal recibida en Uruguay, donde laprensa, en forma casi unánime (El Día, naturalmente, respaldó al gobierno) no dudó en señalar con tono muy crítico que la suspensión respondía exclusivamente a las presiones ejercidas por el gobierno argentino. ${ }^{11} \mathrm{El}$ incidente provocaría finalmente la caída del Ministro de Industrias Gabriel Terra, que presentó renuncia el 7 de setiembre, dándole un nuevo motivo de alegría al canciller argentino. De aquí en adelante, Zeballos se propondría lograr la caída del canciller uruguayo del que tenía una pobre opinión, la que empeoraría sustancialmente a raíz del naufragio del "Constitución” y la postura adoptada por la Cancillería uruguaya al respecto.

$10 \mathrm{El} 12$ de agosto de 1907 Zeballos telegrafió a Guesalaga para felicitarlo en nombre del Presidente Figueroa Alcorta y en el suyo propio. El mismo día le envió un segundo telegrama diciéndole: "Haga conocer verbalmente el telegrama abierto de hoy. Este como el otro van abiertos para producir su efecto". AMREC, DILYF, C.3, c.43, f. 116-118.

11 No podemos dejar de señalar la operación de ocultamiento -no se puede describir de otra forma- que realiza Eduardo Acevedo en sus Anales Históricos (T. V., ob. cit., p. 417-419) en relación con el rol que jugó la aprobación del decreto de pesca en el inicio de la disputa limítrofe. Al hablar de los problemas jurisdiccionales con Argentina suscitados en 1907, Acevedo no incluye mención alguna a dicho decreto, el que solo es aludido en el apartado de la obra referido al "movimiento económico" (p. 473). Como es obvio, siendo él un contemporáneo no pudo ignorar lo sucedido, máxime cuando estaba tan relacionado con los principales protagonistas uruguayos (era primo hermano de Eduardo Acevedo Díaz, Ministro de Uruguay en Buenos Aires, y tío del canciller Jacobo Varela Acevedo). La explicación de ese proceder debe buscarse, creo, en una postura nacionalista, que cuidaba de no ofrecer ninguna información que pudiera avalar futuras reclamaciones argentinas sobre el Río de la Plata, no olvidemos que cuando publicó su obra aún no se había llegado al arreglo definitivo de los límites del Río de la Plata (el Tratado del Río de la Plata y su Frente Marítimo fue firmado por los Presidentes Juan D. Perón y Juan María Bordaberry en noviembre de 1973). 
El naufragio del "Constitución". El 4 de agosto, un día después de la firma del decreto de pesca se produjo el naufragio del vapor uruguayo "Constitución", a menos de dos kilómetros de la costa uruguaya, frente a Conchillas (Colonia). Cuando el vapor de bandera uruguaya "Huracán" auxiliaba a los náufragos, arribó una lancha con marinería argentina armada procedente de Martín García que atracó en el "Huracán" y llevó a los tripulantes a la isla para tomarles declaración, liberándolos al día siguiente. Al tomar el hecho estado público se sucedieron las protestas de la prensa uruguaya, exigiendo al gobierno aclarar lo sucedido. El momento no era el mejor para que el incidente pasara desapercibido: arreciaban las críticas de la prensa ante la suspensión del decreto de pesca, resolución calificada como "acto pusilánime" por un órgano de la oposición. ${ }^{12}$ Mientras tanto, ecos del nuevo incidente aparecieron en la prensa argentina, criticando la postura uruguaya. ${ }^{13}$ El 17 de agosto de 1907, La Prensade Buenos Aires, órgano al que estaba estrechamente vinculado el canciller Zeballos, publicaba una nota criticando la postura de la prensa uruguaya.

El canciller Jacobo Varela Acevedo instruyó al Encargado de Negocios de Uruguay en Buenos Aires, P. Pérez Gomar ${ }^{14}$ para que plantease a Zeballos el disgusto de Uruguay por el incidente. Los reiterados planteos verbales formulados por Pérez Gomar y más tarde, por Acevedo Díaz, solo obtuvieron respuestas dilatorias. Zeballos sostenía que se trataba solo de un mal entendido, y evitaba discutir el tema de la jurisdicción del Río de la Plata. ${ }^{15}$

12La Tribuna Popular, Montevideo, 14 de agosto de 1907: "La pesca y sus cuestiones".

13La Prensa, Buenos Aires, 17 de agosto de 1907: “Jurisdicción argentina en el Río de la Plata. La pretensión uruguaya".

14 El Ministro de Uruguay en Buenos Aires, Eduardo Acevedo Díaz, se encontraba en Asunción, sede ante la que también estaba acreditado.

15 El 24 de agosto de 1907, en una breve misiva al canciller Varela Acevedo, Pérez Gomar le informaba de una entrevista mantenida con Zeballos en la que éste lo había tratado con mucha amabilidad, pero en la que "no hubo oportunidad de tocar la jurisdicción de las aguas del Plata", manifestándole el canciller "que este malentendido en nada podía enfriar nuestras cordiales relaciones". Por su parte, el Ministro Eduardo Acevedo Díaz, en nota a Varela Acevedo del 17 de setiembre de 1907, le informaba de la segunda entrevista mantenida por él con el canciller argentino, en la que había planteado el tema del "Huracán" extensamente, "manifestando de un modo categórico que la satisfacción a mi país se imponía sin reservas; que era ese desagravio, previo, al planteamiento y solución de otros asuntos; que mientras no se obtuviera aquella satisfacción, exigible por el decoro nacional, el problema de jurisdicción de aguas quedaría en pie, pues que era mi convicción la de que mi gobierno ahora y siempre, no reconocería como argentinas las aguas en que se produjo el naufragio, aunque así lo sustentase la cancillería de Buenos Aires en mérito de declaraciones bien o mal arrancadas a los tripulantes de los citados buques, y que en nada podían perjudicar nunca lo que la república del Uruguay consideraba propio y legítimo de su soberanía". Ambas notas en: AMREU, Fondo Ministerio de Relaciones Exteriores, Sección Misiones Especiales Varias, Mueble 4, Caja 1 ("Misión 
No podemos abordar aquí en toda su complejidad las alternativas que tuvo el conflicto diplomático, pero de la documentación analizada surge con claridad lo esencial de las posturas de ambas Cancillerías en ese momento: Varela Acevedo quería obtener la firma de un protocolo por el cual el gobierno argentino condenase el incidente y declarase que no había tenido intenciones de ofender la dignidad de la República Oriental del Uruguay " $n i$ de desconocer la jurisdicción que le corresponde en el Río de la Plata como país ribereño y limítrofe". ${ }^{16}$ Su colega argentino, por su parte, no quería saber nada de un documento que aludiese a la jurisdicción de las aguas; su estrategia era dar largas al asunto hasta que los ánimos se calmasen, evitando asimismo cualquier intento de recurrir al arbitraje.

Mientras estas gestiones se desarrollaban en forma reservada, la prensa uruguaya agitaba a la opinión pública en contra de la política exterior argentina, provocando a su vez algunas reacciones de medios de la otra orilla. El canciller Zeballos, muy molesto por la postura de Varela Acevedo, envió a Guesalagauna nota el 24 de agosto, en la que le advertía que el canciller uruguayo tenía "mal espíritu", se refería a la conveniencia de que Varela Acevedo fuera apartado del cargo y manejaba -por primera vez en la correspondencia que venimos citando- como recurso para torcer el reclamo uruguayo, el tema de la "amenaza" de la revolución nacionalista. En efecto, en esa misma nota Zeballos informaba a Guesalaga de una conversación mantenida con "una persona de Montevideo que goza de toda mi confianza", la que le había informado que "muchas personas sensatas" querían que Varela Acevedo dejara el Ministerio, y agregaba.

"Hay que estimular discretamente este trabajo -instruía a Guesalaga- sin comprometerse
V.E., y la manera de lograrlo es hablar simplemente de los peligros a que expone al Estado
Oriental la acción del canciller, no solamente del punto de vista de la política exterior sino
de la política interna. Hay aquí una gran conspiración "Blanca". En este mismo momento
están gestionando el despacho de un armamento muy considerable que tienen en la
Aduana y fue detenido en la revolución pasada. Nos bastaría con ser indiferentes y dejar
hacer, para que vuelva arder ese país en guerra civil [...] Si el Gobierno Oriental nos
demuestra la mala voluntad con que está procediendo y nos apremia por reclamaciones

Frías", etc.), sobre 4.

16 El planteo de Varela Acevedo exigiendo dicho documento fue trasmitido por el Ministro Guesalaga a Zeballos en nota del 30 de agosto de 1907, en la que adjuntaba una tira de papel donde estaba escrito, de puño y letra del canciller Varela Acevedo, el breve texto en el que explicitaba los términos en que quería se expresara la disculpa argentina. AMREC, DILYF, C.4, c.16 (I), fs. 254-261. 
infundadas, como si se tratara de un 'casus belli', dejaremos hacer, y ese país pagará las indiscreciones de su canciller. ${ }^{17}$

En su respuesta, Guesalaga se muestra muy identificado con la estrategia de Zeballos y sugiere cómo debía ser la conducta a observar por la diplomacia argentina:

\begin{abstract}
"Por allá [se refiere a Argentina] está el "Club" blanco y si por algo cojea, es siempre por el deseo de reconquistar sus posiciones perdidas. [...] Necesitamos pues, por nuestra parte, de calma y disimulo, y pensar antes que todo en el interés de nuestro país, sin importársenos para nada en que por aquí llegue a arder Troya.Que arda, si eso al fin es lo único que los entretiene, pues cuando no tienen política interna, activa, se meten con nosotros". ${ }^{18}$
\end{abstract}

Dicha postura generaría un tácito entendimiento entre la diplomacia argentina y los blancos "radicales". La necesidad de estos últimos, partidarios de la lucha armada, de contar con la permisividad argentina, los llevó a mantener una actitud bastante más moderada en relación con el conflicto jurisdiccional entre ambos países, exhortandoa sus seguidores a no embarcarse en el debate que enfrentaba a las Cancillerías de los dos países. ${ }^{19}$ Por el contrario, la postura del entonces joven diputado Luis Alberto de Herrera, que sostenía en "La Democracia" una prédica contraria a un levantamiento armado y a favor de la participación electoral, merecía de parte del Ministro Guesalagalos calificativos de "elemento de escaso mérito", "entidad negativa" e "intrigante". ${ }^{20}$

Finalmente, y a pesar de todas las gestiones confidenciales realizadas por Guesalaga para evitarlo, el día 24 de octubre de 1907 Uruguay presentó una reclamación formal, cuyo texto Varela Acevedo había sometido a la aprobación del Consejo de Ministros. En la misma se alude brevemente a las múltiples entrevistas mantenidas con el canciller Zeballos y a la solicitud de satisfacción formulada por Uruguay en relación con los sucesos del 4 de agosto, dado que la intervención ejercida 17Zeballos a Guesalaga, Buenos Aires, 24 de agosto de 1907. AMREC, DILYF, C.3, c.43, fs.223-226.

18Guesalaga a Zeballos, Montevideo, 27 de agosto de 1907. AMREC, DILYF, C. 4, c.16 (I), fs.227-238. $19 \mathrm{Al}$ respecto, ver la carta de Abdón Arozteguy, fechada en Buenos Aires el 30 de agosto de 1907, publicada por El Eco del País, Montevideo, 3 de setiembre de 1907: "Una tempestad en un vaso de agua". Dicho diario respondía al Directorio del Partido Nacional. Hemos abordado el tema del rol jugado en el conflicto por "amenaza" de la guerra civil, en la ponencia "El precio de la paz, etc.", ya citada. 20Guesalaga a Zeballos, Montevideo, 3 de setiembre de 1907, AMREC, DILYF, C.4, c.16 (I), cit., fs. $281-283$. 
por autoridades argentinas con motivo del naufragio del vapor "Constitución", "lesiona nuestra soberanía”. La pronta respuesta prometida no había llegado, por lo que, "esa demora en atender una justa reclamación roza la delicadeza de la República Oriental del Uruguay, que quedaría grata por una rápida terminación de este asunto". ${ }^{21}$

La respuesta argentina llegó el 30 de octubre, en una nota en la que se señala que las autoridades de Martín García se habían limitado a "ejercer el derecho de policía fluvial que les corresponde", por lo que no habían resultado lesionados el decoro o la soberanía de la nación oriental. ${ }^{22}$

Cuando trascendió la respuesta, la reacción de la prensa uruguaya fue de unánime rechazo. La nota argentina fue analizada en un Consejo de Ministros en el que Varela Acevedo abogó por retirar al Ministro uruguayo de la capital argentina. Al no recibir apoyo, renunció el día 6 de noviembre de 1907. Al día siguiente, E. Acevedo Díaz entregó al canciller argentinola respuesta uruguaya, en la que el gobierno reiteraba que consideraba que estaba bajo su soberanía el sitio del naufragio del "Constitución", y expresaba su "formal disentimiento" en relación con lo expuesto en la nota argentina. En Uruguay, al trascender el intercambio de notas, se produjo una gran exaltación del sentimiento patriótico y se levantaron muchas críticas en la prensa contra la decisión del gobierno de optar por una postura mesurada.

El 2 de diciembre el Presidente Williman designó a Antonio Bachini como nuevo Ministro de Relaciones Exteriores. ${ }^{23} \mathrm{El}$ nombramiento no fue del agrado de Zeballos, que recelaba de los vínculos que Bachini tenía con el periodismo argentino opositor a su política. En respuesta a una nota de Guesalaga en la que éste le trasmitía una primera impresión favorable sobre el nuevo canciller uruguayo,Zeballos

\footnotetext{
21 Borrador de la nota de reclamación presentada por Uruguay al gobierno argentino, remitido por el Ministro Jacobo Varela Acevedo a la Legación de Uruguay en Buenos Aires (original manuscrito, de puño y letra de J. Varela Acevedo). La nota fue entregada con fecha 24 de octubre de 1907. AMREU, Fondo Ministerio de Relaciones Exteriores, Sección Misiones Especiales Varias, etc. cit.

22Zeballos a Acevedo Díaz, Buenos Aires, 30 de octubre de 1907. AMREC, DILYF, C.4, c.17 (I), fs.599-600.

23 Antonio Bachini (1860-1932) había ejercido el periodismo desde muy joven en Uruguay y en Argentina; se había incorporado al Partido Colorado y durante la guerra civil de 1904 había comandado las fuerzas gubernamentales en Rivera. Al finalizar la misma había sido designado Cónsul General en Buenos Aires, cargo que estaba desempeñando al ser nombrado Canciller.
} 
le contestóexpresando su opinión y reiterándole instrucciones en relación con la "amenaza" de la guerra civil:

"V. E. exagera la sagacidad, el talento y las dotes del nuevo Ministro de Relaciones Exteriores de ese país. Yo he hablado con él por espacio de una hora, y he sacado la consecuencia de que no es sino un paisano vivo, como todos los de su tierra. [...]No olvide V. E., en todas las circunstancias, de hacer comprender la importancia del peligro blanco". ${ }^{24}$

El talante del canciller argentino no era tranquilizador. Desde París, el antecesor de Williman en la Presidencia -y a partir de marzo de 1911, su sucesor- José Batlle y Ordóñez, escribió al Presidente Williman en marzo de 1908 una carta en la que se refiere, entre otros temas, al conflicto con Argentina en estos términos:

"No tiene Vd. que decirme que ha pasado malos ratos con la cuestión internacional; por lo
que me ocurría a mi durante la guerra me he imaginado lo que habrá experimentado Vd.
Yo, sin embargo, tuve la suerte de que las disidencias que a cada paso surgían no se
traslucieran y de que no se me presentara nunca una cuestión tan trascendental como la
de la jurisdicción del río. En estos últimos días he recibido un folleto titulado "Correndo o veo", publicado en San Pablo, que reproduce un discurso del Dr. Estanislao S. Zeballos, dicho en Setiembre de 1906, ante la Junta de Notables reunida en Buenos Aires, y presidida por el Dr. Figueroa Alcorta, con motivo de los proyectos de armamento naval de la República Argentina. Si las ideas del Dr. Zeballosprevalecieran del otro lado del Plata tendríamos que confesar, aun los más amigos de la República Argentina, que nuestro peor enemigo se encuentra en ella. Yo no quiero ver sin embargo, en las opiniones del Dr. Zeballos las que priman en aquel país, pues este personaje tiene allí muchos adversarios y no puede ser considerado como elemento dirigente de la opinión, ni tampoco con condiciones para dirigirla. [...] La verdad es que tenemos que ir armándonos, pues no podríamos dejarnos quitar pacientemente el río. No vale la pena de ser una nación, para que hoy un vecino y mañana otro la retaceen a su antojo. Desgraciadamente ninguna perspectiva halagüeña nos presentaría un conflicto armado con la República Argentina, aún en el caso fuera reducida a la mayor impotencia. Quedaríamos inmediatamente a merced del otro vecino". ${ }^{25}$

24Zeballos a Guesalaga, Buenos Aires, 11 de diciembre de 1907. AMREC, DILYF, C.4, c.17 (V), fs. $972-$ 975 .

25 José Batlle y Ordóñez a Claudio Williman, París, 6 de marzo de 1908. AGN-AW, C.306, c.3. 
Las maniobras de la escuadra argentina. El tercer hechoque agravó la tensión se produjo en la noche del 15 al 16 de abril de 1908, cuando una parte de la escuadra argentina realizó maniobrascon simulacro de combate en aguas de "jurisdicción uruguaya", entre el Banco Inglés y la Isla de Flores. El incidente molestó e inquietó bastante al gobierno uruguayo, que el 23 de abril presentó a la Cancillería argentina una "reclamación verbal muy reservada", señalando la extrañeza que le habían producido dichas maniobras, realizadas a poca distancia de la costa uruguaya, sin haber dado el aviso previo que correspondía; y agregaba que si Uruguay, así como tenía derecho sobre esas aguas "tuviera la fuerza para hacerlas respetar", se podría haber originado fácilmente un conflicto. ${ }^{26} \mathrm{El}$ tono de la protesta uruguaya molestó al canciller Zeballos, pero éste tenía los días contados. ${ }^{27}$

\section{La caída del canciller E. Zeballos y el camino hacia la solución del}

conflicto. El 10 de junio de 1908 Zeballos había presentado en sesión del gabinete un plan secreto de guerra contra Brasil, cuyos lineamientos fueron dados a conocer al otro día por el diario La Naciónde Buenos Aires, provocando una fuerte reacción en contra de la orientación que el canciller había dado a la política exterior argentina. El Presidente Figueroa Alcorta se dio cuenta de que no podría obtener la aprobación parlamentaria para los gastos en armamentos si Zeballoscontinuaba al frente del Ministerio. ${ }^{28}$ Zeballosrenunció y el 22 de junio de 1908 el Dr. Victorino de la Plaza asumió como nuevo Ministro de Relaciones Exteriores.

El gobierno uruguayo, mientras tanto, había nombrado una Junta de Notables para que lo asesorara sobre las posibles soluciones al conflicto. ${ }^{29} \mathrm{~A}$ ello se sumó la 26Memorandum presentado por la Legación de Uruguay en Buenos Aires, 23 de abril de 1908. AMREC, DILYF, C.4, c.18 (II), fs. 1202-1203.

27 Las notas intercambiadas entre ambas cancillerías con motivo de las referidas maniobras, así como informes de los oficiales de la Marina uruguaya sobre las mismas, en: CUADERNOS DE MARCHA, $\mathrm{N}^{\circ}$ 20, "El Río de la Plata", Montevideo, diciembre de 1968, pp. 26-31.

28 Sobre la renuncia de Zeballos, ver: ETCHEPAREBORDA, Roberto, ob. cit, p. 5759 .

29 La Junta de Notables estaba integrada por 32 personalidades, incluyendo a integrantes del Partido Colorado, del Partido Nacional y personalidades católicas. Entre ellos había dos ex Presidentes (Máximo Tajes y Julio Herrera y Obes), ex Ministros de Relaciones Exteriores, ex Ministros del Uruguay en Argentina, catedráticos de Derecho Internacional Público, diplomáticos de larga trayectoria, parlamentarios, etc. La junta se reunió por primera y única vez con el Ministro Bachini el 20 de junio de 1908. Allí se discutió el procedimiento a seguir para que los integrantes de la Junta hicieran llegar sus informes a la Cancillería, optándose por no 
designación, en agosto de 1908, del ya anciano y enfermo Dr. Gonzalo Ramírez (1846-1911) como Ministro uruguayo en Buenos Aires, cargo que asumía por tercera vez. Su prestigio como especialista en Derecho Internacional -disciplina que había enseñado en la Universidad, institución de la que, además, fue Rector- y sus antecedentes de haber solucionado problemas similares, lo hacían un candidato adecuado. Ramírez condujo una larga negociación, pero el texto final del Protocolo fue acordado sin su conocimiento. En efecto, buscando remover obstáculos se negoció en Buenos Aires utilizando personas de confianza del Ministro Bachini, pero también en Montevideo, ya que el gobierno argentino designó en Misión Especial a Ramón J. Cárcano, quien se entendió con el Presidente Williman y con el canciller Bachini, sin consultar a Guesalaga. ${ }^{30}$

El 7 de diciembre de 1909 la prensa uruguaya publicaba una declaración firmada por el Presidente Williman, en la cual el gobierno hacía público el estado de las gestiones diplomáticas con Argentina, afirmando que las mismas estaban bien encaminadas, "sobre la base de retrotraer las cosas a su estado anterior". Allí se señalaba que el Gobierno había pensado plantear la defensa de los intereses uruguayos en términos radicales, pero antes de pasar a solicitar un arbitraje (Uruguay y Argentina tenían firmado un tratado de arbitraje sin limitaciones) había consultado a 32 ciudadanos, de los cuales 28 opinaban que antes de ir a un arbitraje, había que agotar las gestiones amistosas y directas. Y agregaba que urgía "restablecer la cordialidad de las relaciones, para que el Uruguay pueda concurrir a las fiestas

realizar debates entre los integrantes (se argumentó que era imposible mantener el absoluto secreto de los mismos...) y por que cada integrante elaborase su informe, entregándolo directamente al Ministro. Hubo, sin embargo, dos informes con la firma de más de un integrante. Un resumen del contenido de los mismos, elaborado en la Cancillería, y el texto de algunos de dichos informes, se encuentran en el Archivo J. E. Pivel Devoto (UY-AGN, AJPD, Caja 155, Carpeta 502, "Transcripción de documentos. 1908 y s/d"). Creemos que dicha documentación estaba en poder del Ministro Antonio Bachini, cuyo archivo Pivel Devoto obtuvo en donación para el Museo Histórico Nacional, pero suponemos retuvo esta documentación por ser de especial interés para sus investigaciones sobre los límites del Río de la Plata.

30Ramón J. Cárcano (1860-1946) era amigo personal de Figueroa Alcorta, y estaba casado con una hija de Pedro Sáenz de Zumarán -perteneciente a una familia de la alta sociedad montevideana- por lo que habitualmente pasaba los veranos en esta orilla del Plata. Sus vínculos uruguayos fueron muy importantes para reconstruir un espíritu de confianza y cordialidad entre ambos países. En el Archivo José Figueroa Alcorta existen varias cartas suyas al Presidente argentino, en las que le trasmite sus impresiones sobre las negociaciones, los políticos y la sociedad uruguaya en general. 
conmemorativas del Centenario de la Revolución de Mayo, que es también aniversario nuestro..." ${ }^{31}$

Era hora de superar las últimas dificultades: a fines de ese mes la Cancillería argentina decidía el traslado de Guesalaga y por otro decreto designaba al Dr. Roque Sáenz Peña como Enviado Extraordinario y Ministro Plenipotenciario en Misión Especial ante el gobierno uruguayo. El 31 de diciembre de 1909, desde Montevideo, Sáenz Peña informaba al canciller De la Plaza que consideraba aceptado el Protocolo, recibiendo la autorización para firmarlo. Así lo haría, junto a Gonzalo Ramírez, el 5 de enero de $1910 .{ }^{32} \mathrm{El}$ fin del conflicto fue recibido con enorme alivio y alegría en los círculos dirigentes y en la sociedad uruguaya en general. Hoy puede sorprendernos que un texto tan inocuo pueda haber motivado tantas expresiones de alegría. Ello debe advertirnos sobre la tensión y el disgusto con que el conflicto había sido vivido en Uruguay.

La tan mentada "amenaza" del levantamiento blanco pareció a punto de concretarse en ese mismo mes de enero, volviendo a tensar las relaciones bilaterales. Por limitaciones cronológicas y de espacio, no nos referiremos a estos sucesos. ${ }^{33}$

\section{La imagen del otro y la afirmación de las identidades nacionales}

31 La declaración fue transcrita por José Claudio Williman, ob. cit., pp.662-666. 32Por el documento, breve y sin novedades significativas, ambos países declaraban "insubsistente" cualquier resentimiento que pudiera haber quedado con motivo de pasadas divergencias", y acordaban que "La navegación y uso de las aguas del Río de la Plata continuarán sin alteración, como hasta el presente, y cualquier diferencia que con ese motivo pudiese surgir será allanada y resuelta con el mismo espíritu de cordialidad y buena armonía que ha existido siempre entre ambos países". (WILLIMAN, J. C., ob. cit., pp.666-667).

33 Inmediatamente después de firmarse el Protocolo y cuando parecía que las relaciones entre ambos países iban a normalizarse, un nuevo intento revolucionario de los blancos radicales puso a prueba la distensión alcanzada. Las gestiones realizadas por los enviados del Presidente Williman, sumadas al respaldo del Dr. Sáenz Peña y a la comunicación franca de Ramón J. Cárcano con el canciller Bachini, terminaron por disipar aquel nuevo foco de tensión entre ambos gobiernos. Cabe advertir que las limitaciones temáticas y cronológicas del presente texto no nos permiten extendernos sobre el punto, de suma importancia en las relaciones bilaterales. Los designios de los "blancos radicales" se concretarían en un levantamiento de acotado alcance, que tuvo lugar en octubre y noviembre de 1910. Para ese entonces Roque Sáenz Peña era Presidente de la Argentina y adoptó enérgicas medidas para impedir el pasaje de hombres y armas hacia Uruguay, lo que determinó la rápida derrota de la "chirinada". 
Mentalidades, prensa y política exterior. Antes de entrar de lleno a este punto, cabe advertir sobre dos circunstancias que deben ser tenidas en cuenta para una mejor comprensión del tema. La primera de ellas refiere a las diferencias apreciables entre el "utillaje" mental del canciller argentino y su representante en Montevideo, y el de los jóvenes discípulos de Batlle que habían quedado a cargo de la conducción de El Día, cuyo círculo integraba el también joven canciller uruguayo Jacobo Varela Acevedo (1876-1962), hombre próximo a Batlle, a quien había acompañado en su primera administración como Secretario de la Presidencia. Estanislao Zeballos (1854-1923) es, como ya lo señalamos, una de las personalidades de la Generación del 80 que más estudios y comentarios ha motivado. Si bien no podemos extendernos en la caracterización de su personalidad multifacética, que lo ubica como una referencia ineludible de aquella generación del 80, es oportuno recordar -como señala Lilia A. Bertoni- que en octubre de 1887, en su recordado discurso en la Cámara de Diputados sobre los peligros que suponía para la nación argentina el aluvión inmigratorio, Zeballos había dicho: "Dentro de poco nos veremos convertidos como Montevideo en una ciudad sin rasgos", es decir, una ciudad cosmopolita. ${ }^{34}$ Precisamente ese cosmopolitismo fue una de las características del movimiento político fundado por Batlle y Ordóñez, generando en Uruguay recordados debates en los que esta concepción se enfrentó con quienes defendían un nacionalismo de "patria chica". ${ }^{35}$

No estaríamos diciendo nada nuevo si describimos a Estanislao Zeballos como un nacionalista, militarista y racista. El Ministro argentino en Montevideo, Alejandro Guesalaga (1854-1928), estaba cortado por el mismo molde. La visión crítica del representante argentino hacia ese núcleo de políticos batllistases una constante en

34 BERTONI, Lilia Ana, ob. cit., p. 21 y 88.

$35 \mathrm{Al}$ respecto, ver: BARRÁN, José Pedro y NAHUM, Benjamín. Batlle, los estancieros y el imperio británico. Tomo VI, pp. 231-237. Refiriéndose al movimiento político fundado por Batlle y Ordóñez, los autores señalan: "Partido reformador y a la búsqueda del apoyo electoral de los 'humildes', muchos de los cuales eran inmigrantes de corta data, el batllismo demostró poseer un peculiar criterio de la nacionalidad [...]. La nacionalidad consistía en la identificación del país con ideales que lo trascendían: la democracia política, la justicia social, la soberanía económica, conceptos universales y no limitados a las fronteras geográficas de ningún país. [...] Esto explica el rechazo del reformismo a todas las notas xenófobas de la sociedad uruguaya: el odio a las ideas extranjeras de las clases altas, el resentimiento hacia los inmigrantes de ciertos sectores de las medias y populares, la burla y el desdén hacia lo 'gringo' diseminados en todos los sectores sociales”. (ob. cit, .p. 231) 
sus informes, en los que les reprocha su radicalismo, su inexperiencia -en especial a Varela Acevedo- y sin decirlo explícitamente pero dándolo a entender, la condición de "parvenus" de la mayor parte de ellos, aunque en este caso hace la excepción con Varela Acevedo. Algunos de esos "recién llegados" le inspiran comentarios de indisimulado racismo: en nota a Zeballos de fecha 3 de diciembre de 1907 señala que el diario La Prensa de Montevideo está dirigido "por un íntimo amigo de Batlle, el Diputado José $M^{a}$ Sosa (un pardito)"; al comunicar la designación del Dr. Antonio Cabralcomo Ministro de Industrias -para sustituir al renunciante Gabriel Terraadjuntó el recorte del diario que daba la noticia, en el que anotó: "Redactor de El Día", "pardo de color". Comentarios reveladores de la mentalidad de ambos funcionarios argentinos. ${ }^{36}$

La segunda circunstancia a tener en cuenta refiere al vínculo estrecho con órganos de prensa de algunos de los principales actores del conflicto, y el uso (y abuso) que hicieron de aquellos para incidir, no solo en la opinión pública sino directamente en la negociación diplomática. Zeballos tenía en su haber una extensa carrera periodística en La Prensa -considerado por muchos como el diario más importante de Buenos Aires, con un tiraje de unos 125.000 ejemplares-, al que había ingresado en 1874 como cronista, llegando a jefe de redacción y Director en el momento de su designación como canciller. ${ }^{37}$ Tenía, asimismo, estrecha relación con el diario Sarmiento de aquella ciudad.

El representante uruguayo en Buenos Aires, Eduardo Acevedo Díaz, despertó el enojo de Zeballos al conceder frecuentes reportajes a la prensa argentina, "sobre jurisdicción de aguas y dominio Martín García”, por lo que el canciller instruyó a Guesalagapara que llamara la atención del gobierno uruguayo sobre el punto, ya que: "No es regular, ni conviene a la amistad internacional que los diplomáticos debatan por la prensa los asuntos en que intervienen". ${ }^{8}$ J. Varela Acevedo tuvo a su 36Antonio Cabral, joven abogado que murió prematuramente mientras ocupaba dicha cartera, era hombre de confianza de Batlle y a él atribuía el líder colorado -en carta a Williman, fechada en París el 4 de noviembre de 1907- la autoría de algunos de los artículos publicados en El Día defendiendo la postura uruguaya en el conflicto. UY-AGN, Archivo Williman, Caja 305.

37 MAYOCHI, Enrique Mario, "El Periodismo argentino del Centenario 1901-1916", San Isidro, Provincia de Buenos Aires, Academia de Ciencias y Artes de San Isidro, 2000.

38Zeballos a Guesalaga, Buenos Aires, 2 de noviembre de 1907, AMREC, DILYF, C.4, c.17 (I), f. 631. 
disposición el diario fundado por Batlle y Ordóñez, El Día, para dar a conocer su opinión a través de oficiosas entrevistas y, si nos atenemos a las sospechas del Ministro Guesalaga, a través de artículos de su propia pluma. Mucho más importante era el vínculo con la prensa del Cónsul General en Buenos Aires y luego, canciller uruguayo, Antonio Bachini. Periodista prestigioso, había ejercido dicha profesión en El Diario de Buenos Aires, el órgano fundado por Manuel Laínez y opuesto fuertemente a la política de Zeballos.

Por su parte, el sucesor de Eduardo Acevedo Díaz al frente de la Legación uruguaya en Buenos Aires, el Dr. Gonzalo Ramírez, no solo hizo declaraciones en la prensa sino que llegó a publicar una serie de notas sobre el tema de la jurisdicción del Río de la Plata, bajo el seudónimo de "Ignotus" ${ }^{39}$ En efecto, existió un uso de la prensa en la batalla diplomática, que también se tiñó, como es habitual, con los enfrentamientos de la política interna. Por eso, cuando constatamos que un periodista experimentado como Antonio Bachini, ya en su condición de canciller, concedió una entrevista a la revista argentina Caras y Caretas, en la que afirmó que "el pueblo uruguayo vería con buenos ojos la renuncia del doctor Zeballos", no podemos pensar que aquellas declaraciones fueron una simple imprudencia. ${ }^{40}$

Por ello, tenemos que advertir que la documentación relevada, aunque de origen y características diversas, en algunos casos se relaciona por hilos sutiles y encubiertos.

Por último, debemos tener en cuenta que en lo atinente a su relación con la prensa, al parecer el gobierno uruguayo contaba con una situación más favorable que su par argentino: en Buenos Aires algunos órganos de prensa importantes, como La Nación y El Diario, sostenían una posición contraria a la política de Zeballos. En Montevideo, casi toda la prensa apoyó los derechos de Uruguay en la disputa con el país vecino, y si hubo críticas al gobierno de Williman fue, en la mayoría de los casos, por no tener una postura más radical en aquel enfrentamiento. Los "blancos radicales", sin embargo, tuvieron una postura algo diferente. ${ }^{41}$

39 IGNOTUS, "La cuestión del Plata. Pruebas de nuestro derecho", Revista Histórica de la Universidad, Montevideo, Año II, Agosto de 1909, No 5, pp. 498-550.

40Caras y Caretas, Buenos Aires, 29 de febrero de 1908: "Con el Canciller uruguayo". 41 El periódico nacionalista, El Eco del País, publicó un artículo en noviembre de 1907 -al parecer inspirado por el Dr. Martín Aguirre, Presidente del Directorio del Partido Nacional- en el que se sostenía que, debido a la escasa información 
Argentina, el gran hermano. La conciencia de la pequeñez de Uruguay en relación con el vecino rioplatense está presente tanto en los diplomáticos y periodistas argentinos como en sus pares uruguayos aunque, naturalmente, según el caso, dicha circunstancia fue vivida y reflejada en forma diferente. Si quisiéramos sintetizar -con cierto esquematismo- lo esencial de ambas miradas, podríamos decir que en la perspectiva argentina y concretamente, en la correspondencia entre el canciller Zeballos y el Ministro Guesalaga, puede percibirse una molestia -no exenta de cierta sorpresa- ante la postura uruguaya, que no quiere apearse de exigir una satisfacción del gobierno argentino ante lo que es percibido como una vulneración de la soberanía nacional. En la perspectiva uruguaya, hay una opinión generalizada que incluye a las autoridades y a la casi totalidad de la prensa- que percibe a Argentina como el país grande y fuerte que abusa de la debilidad de su pequeño vecino. De ambas perspectivas y "representaciones" hay muchos ejemplos, algunos de los cuales ofrecemos a continuación.

Zeballos y Guesalagacritican la postura uruguaya -la de los funcionarios del gobierno y la de otros protagonistas- por considerarla poco realista en cuanto a las posibilidades reales del país. En setiembre de 1907, el ex Presidente Julio Herrera y Obes había declarado que era una torpeza discutir el derecho de Uruguay a la jurisdicción del Río de la Plata, "cuando todos los antecedentes, todos los tratados están contestes en reconocernos absolutos soberanos sobre la mitad de nuestras aguas fluviales". Al trasmitir a Zeballos dichas manifestaciones, Guesalaga comentó: "Fíjese V. E. la arrogancia con que hablan estos señores, parece que representan a la Prusia...".42

disponible, no era posible saber "de parte de quién está la razón” y, al día siguiente, cuando Uruguay presentaba su respuesta a la nota argentina, se dedicó a criticar al gobierno de Williman por su falta de experiencia. El Eco del País, Montevideo, 6 de noviembre de 1907: "La cuestión internacional"; y 7 de noviembre de 1907: "Gobierno de inexpertos". Es claro que dicha postura mostraba la cautela de los sectores nacionalistas que pensaban recurrir nuevamente al levantamiento armado y necesitaban un grado de permisividad para sus preparativos revolucionarios en la vecina orilla.

42Guesalaga a Zeballos, Montevideo, 17 de setiembre de 1907. AMREC, DILYF, C. 4, c.16 (II), f.s. 372382. El reportaje a J. Herrera y Obes fue publicado en La Tribuna Popular, Montevideo, 17 de setiembre de 1907: "Nuestra soberanía fluvial. La cuestión palpitante. Entrevista con el doctor Julio Herrera y Obes". 
La notoria superioridad de fuerzas de la República Argentina es utilizada por Zeballos para argumentar a favor de su postura. Así, en setiembre de 1907 escribe a Guesalaga:

\begin{abstract}
"La nota uruguaya formula moderadamente sus reservas sobre el punto en que naufragó el 'Constitución'. No olvide V. E. de acentuar en toda oportunidad que se le presente, de palabra y por escrito, que nosotros estamos en posesión de ese punto y que mantendremos la jurisdicción argentina en esas aguas. Por lo demás, esto es una garantía para el Uruguay, pues nuestra abundancia de recursos nos permite hacer gastos que ese país no podría afrontar, de dragado, iluminación y conservación de canales”. ${ }^{43}$
\end{abstract}

Una visión similar es expresada por Guesalaga al aludir a la eventualidad de que el gobierno uruguayo decidiese el retiro de su representante en Buenos Aires:

"Si esto es así, hay que dejarlos, no darle mayor importancia al asunto. No creo que deberíamos nosotros hacer lo mismo, pues sería atribuirles importancia de gran nación. [...]Así, en tal hipótesis, los trataríamos como se debe, como una Provincia". ${ }^{44}$

Es difícil encontrar una formulación más clara de la dificultad de los funcionarios argentinos para ver a Uruguay como un país soberano, con reivindicaciones propias. Esta dificultad parece haber sido la responsable de que, invariablemente, atribuyeran el reclamo uruguayo en relación con el Río de la Plata a una manipulación del Barón de Río Branco. Detrás de cada acción uruguaya Zeballos creía ver al canciller brasileño, con quien mantenía un enfrentamiento personal y político. Es cierto que la prensa uruguaya -ya fuese por sugestión de la Cancillería o de motu propio- agitaba la sombra de Brasil, dando a entender que Uruguay tenía quien lo defendiese. Pero hay claros indicios de que el gobierno uruguayo intentaba aprovechar la coyuntura de tensión regional entre sus dos grandes vecinos para obtener de Brasil algo que venía reclamando reiteradamente desde la década de 1860. ${ }^{45}$ Guesalaga informaba que desde la Cancillería oriental se filtraban rumores de próximos entendimientos con Brasil en relación con la obtención del condominio de las aguas limítrofes de la Laguna Merín y el Río Yaguarón. Los preconceptos del representante argentino lo indujeron a cometer errores de apreciación: sostuvo

43Zeballos a Guesalaga, Buenos Aires, 7 de noviembre de 1907. AMREC, DILYF, C.4, c.17 (II), fs. 729731.

44Guesalaga a Zeballos, Montevideo, $1^{\circ}$ de noviembre de 1907. AMREC, DILYF, C.4, c.17 (I) fs. 623630. La palabra "Provincia", está subrayada en el original.

$45 \mathrm{Al}$ respecto, ver: DE LOS SANTOS FLORES, Clarel, ob. cit. passim. 
reiteradamente que la opinión pública uruguaya no estaba pronta para una aproximación a Brasil y, más desacertado aún, creyó que los anuncios de Brasil de su intención de devolver a Uruguay el condominio de las aguas de la Laguna Merin y el Río Yaguarón respondían a una política de engaño de Río Branco, pero que nunca se materializarían en un Tratado. ${ }^{46}$ En marzo de 1908 Zeballos instruyó a Guesalaga para desanimar al gobierno uruguayo en su política de aproximación a Brasil. La estrategia a emplear partía de la indudable superioridad de fuerzas:

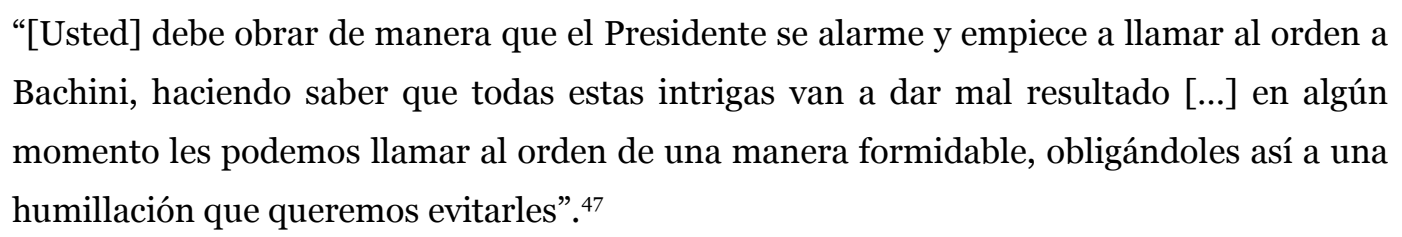

Un mes más tarde tendrían lugar las maniobras de la escuadra argentina a las que ya nos hemos referido. Existen elementos de juicio para atribuirles una intencionalidad no ajena al conflicto entre ambos países. El Ministro de Gran Bretaña en Montevideo, Robert. J. Kennedy, relató al Foreign Office la conversación confidencial mantenida con el Ministro Bachini en un viaje a Fray Bentos, en el que éste le había informado sobre las relaciones entre Uruguay y Argentina, que el canciller uruguayo calificó como "dolorosamente tirantes". Según Kennedy, al referirse a las maniobras de la escuadra argentina, "Él caracterizó este procedimiento como deliberadamente descortés y calculado para causar excitación y alarma entre una población como la de Uruguay 'que está siempre con el temor de una revolución'." El Ministro británico, refiriéndose a Guesalaga, agregó: “Mi colega argentino me informó, en confianza, que las maniobras de la escuadra argentina fueron especialmente dirigidas a castigar a Uruguay por su ostentosa exhibición de amistad con Brasil [...]”. ${ }^{48}$

Argentina, el país fuerte que abusa del débil. El diario nacionalista " $L a$ Tribuna Popular" - calificado por Guesalaga como "diario populachero y sin

46El Tratado de Rectificación de Límites se firmó en Río de Janeiro el 20 de octubre de 1909 y fue ampliamente festejado en Uruguay, redundando en un notable mejoramiento de la imagen de Brasil y de su canciller, en la opinión pública uruguaya.

47Zeballos a Guesalaga, Buenos Aires, 11 de marzo de 1908. AMREC, DILYF, C.4, c.18 (I), fs. 1110-1113.

48 Robert J. Kennedy a Sir Edward Grey, Informe anual sobre el año 1908, Despacho No 2 , Montevideo, 7 de enero de 1909. En: NAHUM, Benjamín. Informes diplomáticos de los Representantes del Reino Unido en el Uruguay. 1903-1911, Ministerio de Educación y Cultura, Montevideo, 1991, pp. 112-114. 
importancia que no tienela menor autoridad"49- fue uno de los más duros críticos de la política exterior argentina, advirtiendo: "hay que decirlo muy claro: desde hace muchos años pretende el gobierno de la casa rosada, que, como nosotros no tenemos elementos de defensa, debemos cederles toda la jurisdicción del Plata, para ellos fortificarlo por el Norte y Sud, a su gusto"..$^{\circ}$

Similares reacciones aparecerían en la prensa uruguaya al conocerse la respuesta argentina a la reclamación uruguaya por el incidente del "Constitución”. El gubernista El Día, defendiendo al Presidente Williman de los ataques periodísticos de que había sido objeto por no haber respaldado posturas más radicales, volvía sobre el tema del fuerte que abusa del débil:

\footnotetext{
"Hay que convencerse: la solución ideal, sería tener a Montevideo fortificada, sería tener escuadra, sería tener cañones, para ir al Canal Nuevo y enseñarle al Canciller Argentino que cuando se ha tenido la prudencia de respetar la soberanía de los pueblos fuertes como por ejemplo la soberanía de Chile y del Brasil, se debe igualmente tener la prudencia de respetar la soberanía de los pueblos débiles como el Uruguay". ${ }^{1}$
}

Días más tarde insistiría en el planteo, a través de una caricatura en la que, bajo el título de "El terrible Zeballos", se mostraba al canciller argentino parado como un coloso sobre el Río de la Plata. La caricatura estaba acompañada de unos versos, titulados "Un coloso de comedia", en los que Zeballos era tildado de "matón". ${ }^{2}$

El uso de la imagen del fuerte que abusa del débil no solo se expresa en la prensa sino que está presente en la documentación oficial. Un pasaje de la reclamación verbal "muy reservada" presentada por la Cancillería uruguaya para protestar ante las maniobras de la escuadra argentina, dice

\footnotetext{
"Bien se comprende que si la República Oriental del Uruguay, así como tiene el derecho sobre esas aguas tuviera la fuerza para hacerlas respetar, fácil hubiera sido un conflicto originado por ese olvido de nuestra soberanía y por la acción que una sorpresa semejante hubiera podido determinar de parte de nuestros elementos defensivos. Sin embargo como
}

49Guesalaga a Zeballos, Montevideo, 19 de agosto de 1907. AMREC, DILYF, C.3, c.43, fs. $190-195$.

50La Tribuna Popular, Montevideo, 14 de agosto de 1907: "La pesca y sus cuestiones".

51El Día, Montevideo, 8 de noviembre de 1907: “iLa gran injusticia!”.

52El Día, Montevideo, 12 de noviembre de 1907: "Nota Gráfica. El terrible Zeballos (por Carolus). UN COLOSO DE COMEDIA!". 
esta omisión se produce a raíz de otras análogas aunque de menor importancia, el Gobierno del Uruguay si bien no tiene a su disposición medios materiales para desplegarlos como signo de la soberanía nacional en la línea de su jurisdicción, tampoco está dispuesto a tolerar en silencio el desconocimiento de sus derechos que hiere doblemente la susceptibilidad patriótica porque la inconsideración parecería acompañada de un abuso de la fuerza. Frente a la tradicional amistad de ambos países, esos hechos adquieren un carácter singularmente anómalo, pues ni esa amistad ha desaparecido para justificarlos, ni el carácter caballeresco del pueblo argentino concuerda con el descomedimiento del fuerte hacia el débil”. ${ }^{33}$

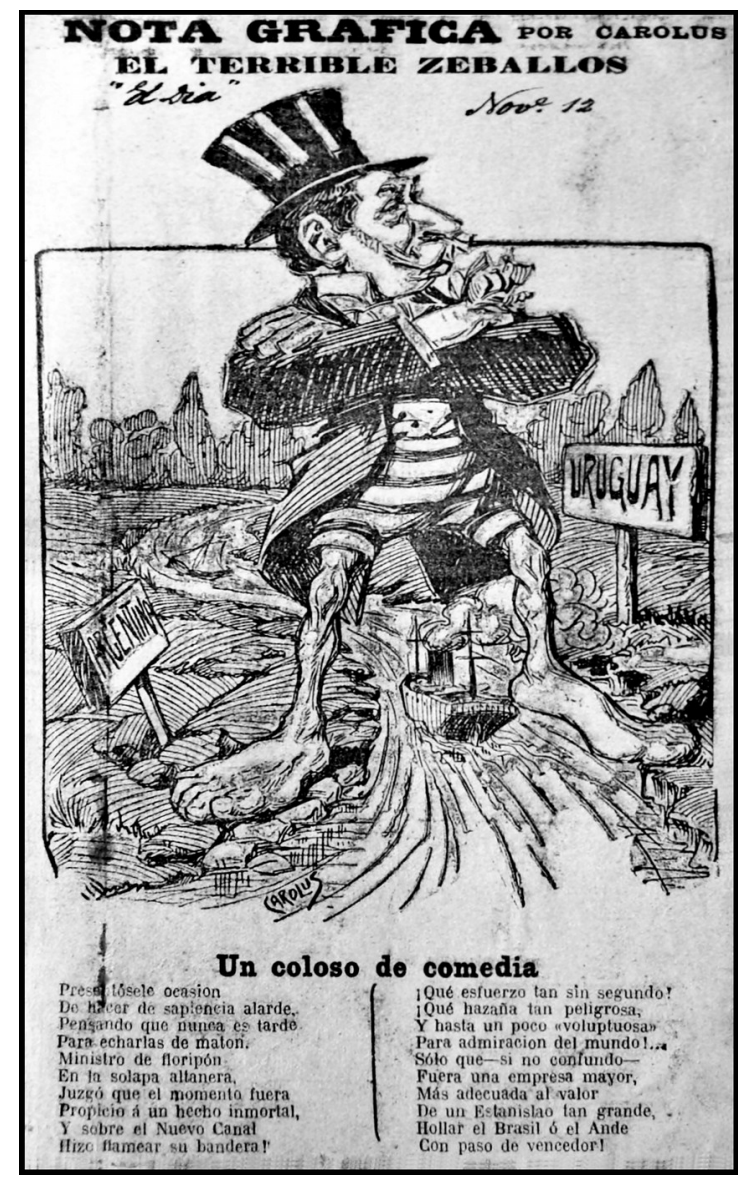

\section{UN COLOSO DE COMEDIA.}

Presentósele ocasión

De hacer de sapiencia alarde, Pensando que nunca es tarde Para echarlas de matón. Ministro de floripón En la solapa altanera, Juzgó que el momento fuera Propicio a un hecho inmortal. Y sobre el Nuevo Canal Hizo flamear su bandera! iQué esfuerzo tan sin segundo! ¿Qué hazaña tan peligrosa, Y hasta un poco "voluptuosa" Para la admiración del mundo!... Sólo que -si no confundoFuera una empresa mayor, Mas adecuada al valor De un Estanislao tan grande, Hollar el Brasil o el Ande Con paso de vencedor!".

El Día, Montevideo, 12 de noviembre de 1907: "Nota Gráfica por Carolus. El terrible Zeballos".

\section{El tono de la reclamación molestó al canciller argentino. Al informar a}

Guesalaga sobre la presentación de la misma, comentó:

“Está escrita 'en compadre', pues hace alusión a que el fuerte abusa del débil [...] Conviene que por intermedio de algún amigo íntimo le haga dar un susto al Presidente

53 "Memorándum" del gobierno uruguayo, presentado a la cancillería argentina por el Ministro Eduardo Acevedo Díaz, Buenos Aires, 23 de abril de 1908. AMREC, DILYF, C.4, c.18 (II),fs. 12021203. 
haciéndole notar que la forma irrespetuosa de la reclamación dará lugar probablemente a una contra reclamación y pedido de satisfacciones por el gobierno argentino". ${ }^{54}$

Convengamos en que el talante de sus instrucciones no era el más adecuado para revertir la imagen que la prensa uruguaya tenía del proceder del gobierno argentino.

\title{
La exaltación del sentimiento patriótico en ambas orillas del Plata.
}

En agosto de 1907, al iniciarse la disputa jurisdiccional, el órgano uruguayo de orientación blanca La Democracia había afirmado: "Gracias a Dios en la república ya existe espíritu patriótico y ya las diferencias internas entre blancos y colorados no perjudican la perspectiva de los asuntos internacionales". ${ }^{55} \mathrm{El}$ desarrollo posterior del conflicto puso en evidencia múltiples manifestaciones de ese espíritu, tanto en Uruguay como en la vecina orilla. Ello fue más evidente en el mes de noviembre de 1907, cuando se estuvo al borde de la interrupción de relaciones diplomáticas. En ese momento El Nacional de Buenos Aires planteó el peligro representado por la presencia de numerosos orientales en la administración pública de aquel país, circunstancia de la que responsabilizaba al General Julio A. Roca. El brote "antioriental" tuvo como detonante la denuncia de un intento de espionaje. ${ }^{56}$ Decía $E l$ Nacional:

\begin{abstract}
"Se ha hecho público, con pelos y señales, el plan del ex canciller uruguayo doctor [Varela] Acevedo para lograr por medio del soborno ejercido en altos empleados de la cancillería argentina, la adquisición de importantísimos secretos de estado. La misma información agrega que un espía enviado expresamente por la cancillería uruguaya, dirigido por un funcionario oriental en ésta, inició esas gestiones de soborno [...]. Teniendo en cuenta los sentimientos patrióticos del individuo -y la exaltación característica de ese sentimiento en los orientales- demás está decir que el gobierno argentino no puede confiar ningún resorte administrativo a ningún oriental”. ${ }^{57}$
\end{abstract}

También en Montevideo el conflicto había tensado la vena patriótica. Tan solo tres días después de la aparición del artículo publicado por El Nacional, el 11 de

54Zeballos a Guesalaga, Buenos Aires, 23 de abril de 1908. AMREC, DILYF, C.4, c.18 (II),fs. 12081209. Las palabras “En compadre”, están subrayadas en el original.

55La Democracia, 13 de agosto de 1907: "Suspensión improcedente".

56 La denuncia se había publicado en el diario Sarmiento, Buenos Aires, 6 de noviembre de 1907:

"Grave descubrimiento. Tentativa de sustracción de Planos militares", etc.

57El Nacional, Buenos Aires, 8 de noviembre de 1907: "Grave". 
noviembre de 1907 un mitin convocado por la "Asociación de Estudiantes" para protestar contra Argentina y en respaldo al renunciante Varela Acevedo, terminó en una manifestación no autorizada, que marchó con una bandera uruguaya y un retrato de Artigas al frente, entonando el himno nacional. Los estudiantes quisieron dirigirse al Consulado argentino pero la policía se los impidió, suscitándose algunos incidentes. Marcharon entonces hasta la plaza Constitución y, desde allí, hasta la casa del renunciante canciller Varela Acevedo (quien ioh paradoja! vivía en la calle Buenos Aires) profiriendo gritos contra la Argentina, resultando infructuosas las exhortaciones del ex canciller para que se limitaran a vivar a Uruguay. ${ }^{58}$

En nota a Zeballos en la que evaluaba las repercusiones del conflicto bilateral-y pensando, quizás en el incidente descrito-Guesalaga expresó:

"[muchas] personas serias y dignas [...] deploran lo sucedido y consideran lo del incidente algo así como un disgusto entre hermanos, como una pelea de amor[...] la juventud, no hablo de esa juventud que procede de las antiguas familias del país, esa no, sino la otra, la de la clase media o general si es posible decir esto para sintetizar el pensamiento, esa juventud, no nos quiere, y entre la primera existen ánimos predispuestos, como el de Jacobo Varela Acevedo, que nos guarda sus ideas, empapadas en el pensamiento de Carlos $\mathrm{M}^{\mathrm{a}}$ Ramírez, en la sangre de Artigas, en su odio a los porteños, como califican por acá a todos los argentinos".

$\mathrm{Al}$ rechazo social implícito en aquel comentario, se sumó el racial ya que, al leer la misiva, Zeballos anotó junto a la expresión "esa juventud", la interrogante:“¿mestiza?”, subrayándola. ${ }^{59}$

En el marco de la tensión generada por el conflicto hubo muchas expresiones a favor del aumento de armamentos,destacándose la prédica en ese sentido sostenida por el senador del Partido Colorado Carlos Travieso, presidente del Club "Rivera", que organizó un mitin para promover la adquisición de armamentos. No es fácil, sin embargo, discernir en qué medida la tensión con Argentina fue determinante para la adquisición de armamentos que tuvo lugar durante la presidencia de Williman, o si la misma fue utilizada

$58 \mathrm{El}$ relato sobre el acto -que tuvo como oradores, entre otros, a Washington Beltrán y Lorenzo Carnelli, que serían luego importantes dirigentes del Partido Nacional- y los sucesos posteriores, apareció en los diarios montevideanos El Siglo, La tribuna Popular y El Día, del 12 de noviembre de 1907.

59Guesalaga a Zeballos, Montevideo, 16 de noviembre de 1907. AMREC, DILYF, C.4, c.17 (V), fs. 912914.La palabra "porteño", subrayada en el original. 
parajustificar las razones reales para armarse, que respondían al siempre presente temor a un nuevo levantamiento del Partido Nacional. ${ }^{60}$

Los extremos a que podía llegar la exaltación patriótica en ambas orillas del Plata fueron señalados en la columna "Charlas de un montevideano" que publicaba "El Día" con la firma de "Suplente" (Samuel Blixen). Decía la nota que un comerciante montevideano, intentando promover las ventas, había llenado su vidriera de corbatas verdes, exhortando a usarlas a modo de distintivo, a aquellos que deseasen protestar contra la Argentina. Después de señalar lo absurdo del planteo, y en obvia alusión al artículo del diario bonaerense antes referido, decía el reconocido periodista:

"Lo único que puede consolarnos, es que nuestros vecinos caen en extravíos aun más deplorables. Un diario bonaerense nos echa en cara nuestra ingratitud. Dice que pagamos mal el espléndido festín que la prosperidad argentina ofrece a los cien mil orientales, más o menos hambrientos, que residen del otro lado del Plata...”.

Pero, argumenta, si los orientales habían conquistado "muchos de los más altos puestos en la administración”, ello se debía a sus capacidades y a sus méritos. La defensa que a continuación hacía de esa emigración uruguaya es un revelador testimonio de los fuertes lazos existentes entre las sociedades de ambas orillas del Plata:

\begin{abstract}
"Por caridad se otorga un mendrugo, pero no se sirve el bocado más exquisito sino al que se lo gana mereciéndolo. Por limosna no se dan ejércitos a mandar, como al general Villegas, que pagó su grado en moneda de victorias. [...]Por limosna no se entregan los periódicos, que son el pensamiento y la voz del pueblo, a la inteligencia y a la pluma de escritores extranjeros, y si Daniel Muñoz, Antonio Bachini, Julio Piquet, Alfredo Duhau, Agustín de Vedia, Javier de Viana, Manuel Bernárdez, Arturo Jiménez Pastor, y otros muchos han ganado buenos sueldos en el vecino país, esos sueldos fueron ganados con el sudor fecundo y constante de sus claras inteligencias". ${ }^{61}$
\end{abstract}

60 En nota a Zeballos del 8 de noviembre de 1907 -el mismo día en que la prensa uruguaya publicó las notas intercambiadas por ambas cancillerías- el Ministro Guesalaga se refiere al meeting que está organizando el Club "Rivera" y dedica un comentario humorístico (muy raro en él) al Senador Travieso, del que dice "procede constantemente de acuerdo con su apellido siempre que se trata de nuestro país". Agrega que ese mismo día se ha publicado en el diario gubernista El Día un artículo "escrito por uno de sus redactores, amigo y compañero del ex Ministro Varela Acevedo y de su misma edad Dr. Amézaga, en el cual al defender la actitud del Presidente de la República y del ex Ministro, encarece la necesidad urgente de que el Uruguay tenga buques de guerra y fortifique sus costas para defender la jurisdicción en el estuario del Plata”. AMREC, DILYF, C.4, c.17 (II), fs. 741743.

61El Día, Montevideo, 14 de noviembre de 1907: "Charlas de un montevideano". 
El canciller Zeballos, por el contrario, lejos de preocuparse por la exaltación del sentimiento patriótico argentino, lo veía con entusiasmo. En marzo de 1908 escribió a Guesalaga:

\begin{abstract}
"La prédica y la polémica en los diarios de Montevideo y Argentina nos conviene, por levantar el espíritu público en Buenos Aires, donde el folleto de Sanabria, lejos de hacer un mal, ha hecho un bien inmenso! Tengo que estar conteniendo al ejército y a la marina que quieren hacer manifestaciones públicas, y de la misma manera a la Universidad y a mis amigos". ${ }^{2}$
\end{abstract}

Sin embargo, debemos preguntarnos qué eco tuvieron en otros sectores sociales aquellas y estas expresiones de la prensa política o de la juventud universitaria. Por las limitaciones señaladas al inicio de este trabajo no estamos en condiciones de aventurar una respuesta para el caso argentino. En relación con Uruguay, hay indicios de que aquel clima de exaltación patriótica abarcó a sectores más amplios de la sociedad. El memorialista Guillermo García Moyano señala que,siendo niño, asistía con frecuencia a un cinematógrafo de Plaza Independencia y recuerda que, en agosto de 1907 se proyectaba allí un documentalen el que se veía al canciller Zeballos, cuya aparición provocaba una silbatina general. ${ }^{63} \mathrm{El}$ conflicto también tuvo eco en la poesía nativista: José Alonso y Trelles ("El Viejo Pancho") aludió al mismo en una poesía que publicara en abril de $1908 .{ }^{64} \mathrm{El}$ rechazo a la política del canciller argentino también se expresó en el carnaval montevideano. Así lo atestiguan estos versos que cantó la murga "Pobres Negros Orientales" en febrero de 1909: "Si piensa que el oriental/ Con paradas se abatata/ A Zeballos le ha salido/

62Zeballos a Guesalaga, Buenos Aires, 11 de marzo de 1908. AMREC, DILYF, C.4, c.18 (I), fs. 1110-1113. El folleto aludido es el ya referido "Correndo o veo".

63 Señala García Moyano: " $Y$ en aquel Salón improvisado, en una matinée para gente menuda, el Dr. Zeballos se ganaba una formidable rechifla. Incluso con la complicidad del empresario Carranza y del operador que detenía la máquina en el momento en que el Canciller saludaba, de modo que la rechifla ensordecedora pudiera durar varios minutos". GARCÍA MOYANO, Guillermo, "Pueblo de los Pocitos", en LERENA ACEVEDO, Josefina y otros, Memorias del Novecientos, Montevideo, Ed. Banda Oriental, 2007, p. 270-271. (Debo este dato a la Prof. Stella Sarasúa).

64 La poesía apareció en la revista nativista El Fogón; en una de sus estrofas decía: "Dejame tomar mate, /y contame qué es eso e las riberas, /de que hablaban el patrón con el pueblero/la otra mañana al comenzar la hierra. // iNada, en gracia de Dios! Que los porteños/no nos dejan del Plata ni la arena, y anda un diario pagao por don Zebayos/mojándonos la oreja...”. ALONSO Y TRELLES, José (“El Viejo Pancho"), Obras completas. Ed. de Gustavo San Román, Montevideo, Linardi y Risso, 2005, p. 169-170. (Debo este dato a la Lic. Alicia Rebollo). 
El tiro por la culata/Pues antes de permitir/Semejante humillación/Preferimos ver primero/ En escombros la nación". ${ }_{55}$

\section{El conflicto y la construcción de la historia nacional en Uruguay ${ }^{66}$.} El período en que se desarrolló la disputa con Argentina coincide con un momento relevante en los esfuerzos por construir una historia nacional en Uruguay, condición sine qua non para la afirmación del sentimiento nacional. Esta coincidencia es de por sí significativa. Pero a ello hay que sumarle la participación que tuvieron en los debates generados por el conflicto limítrofe, algunos de los principales referentes de aquel proceso de construcción del relato histórico. Veámoslo.

Juan Zorrilla de San Martín (1855-1931), el "poeta de la Patria", se había destacado en las etapas iniciales de la reivindicación de la figura de Artigas, así como en la afirmación de un relato sobre los orígenes de la Nación, con "La Leyenda Patria" (1879). Entre 1907 y 1909, mientras se desarrollaba lo más álgido del conflicto, Zorrilla escribía su "Epopeya de Artigas", cumpliendo con un encargo del gobierno de Williman. ${ }^{67} \mathrm{El}$ poeta había sido durante muchos años catedrático de Derecho Internacional Público en la Facultad de Derecho y al iniciarse el conflicto su opinión fue requerida por la prensa uruguaya: los diarios El Tiempo y El Siglo de Montevideo dieron a conocer los argumentos de Zorrilla defendiendo los derechos

65 El fragmento fue publicado en: La Tribuna Popular, Montevideo, 23 de febrero de 1909 p. 2. (Debo este dato a la historiadora Milita Alfaro).

66 Por las limitaciones ya expuestas, en este breve apartado me referiré solo a Uruguay. No obstante ello, es preciso recordar que Estanislao Zeballos comparte con los protagonistas uruguayos que mencionaremos aquí, la condición de constructor del relato histórico de su país. Su abundante producción es enumerada minuciosamente por Roberto Etchepareborda en el apéndice de su ya citado trabajo (Zeballos y la política exterior argentina, pp. 113-121), y analizada en varios capítulos del volumen colectivo coordinado por Sandra Fernández y Fernando Navarro (Scribereestagere), ya citado.

67 El decreto fue firmado el 10 de mayo de 1907 por Claudio Williman, su Ministro de Interior, AlvaroGuillot, y el de Relaciones Exteriores, J. Varela Acevedo, (WILLIMAN, J.C., ob.cit, pp. 375-377). Por dicha resolución se disponía la erección de un monumento a José Artigas en la Plaza Independencia, se llamaba a licitación para la presentación de bocetos entre escultores uruguayos y extranjeros y se designaba a Juan Zorrilla de San Martín para que prepara "una Memoria sobre la personalidad del General Artigas, y los datos documentarios y gráficos que puedan necesitar los artistas”. Al respecto, ver: PIVEL DEVOTO, Juan E. De la leyenda negra al culto artiguista, ob. cit, pp. 231-274; y FREGA, Ana. "La construcción monumental de un héroe", ob. cit. passim. 
jurisdiccionales de Uruguay en el Río de la Plata. Ello le ganó la antipatía del Ministro Guesalaga, que aludió en estos términos al artículo que Zorrilla publicara en El Siglo:

"El Dr. Zorrilla de San Martín, el poeta de la juventud, jurista conocido, promotor de la excursión a la playa de la Agraciada el 19 de Abril y el que declaró que no era cierto de que los estudiantes al avistar la Isla de Martín García hubiesen silvado [sic] a nuestra bandera, cuando si cometieron ese acto fue a consecuencia de sus peroraciones a bordo, en su forma sempiterna, publica esa carta [...] para salir del olvido" ${ }^{68}$

Zorrilla de San Martín integró la Junta de Notables que asesoró al gobierno en relación con el conflicto. También la integraron, José Manuel Sienra Carranza y José Pedro Ramírez, ambos abogados y periodistas que habían participado en el proceso de construcción de la figura de Artigas como máximo héroe nacional. ${ }^{69}$

En el caso de la familia Ramírez, resulta interesante comprobar que no solo aparecen involucrados, bajo diferentes formas, los doctores José Pedro y Gonzalo Ramírez -este último en el triple papel de representante uruguayo en Buenos Aires, integrante de la Junta de Notables y polemista anónimo- sino también el Dr. Carlos María Ramírez, ya fallecido. Aunque la afirmación pueda resultar risueña, lo cierto es que su presencia sobrevuela los debates y la sola mención de su nombre despierta encono en el Ministro Guesalaga.Carlos María Ramírez (1848-1898), abogado, periodista y político, había editado en 1884 un libro reivindicando a Artigas..$^{70}$ Pero no era ésta la única razón por la que tendría "mala prensa" en la correspondencia diplomática argentina. Al iniciarse el conflicto jurisdiccional,Guesalaga informó a

68Guesalaga a Zeballos, Montevideo, 13 de agosto de 1907. AMREC, DILYF, C. 3, c. 43, f. 126. El artículo, sin firma, que Guesalaga atribuye a Zorrilla, fue publicado por El Siglo el 10 de agosto de 1907: "Jurisdicción del Río de la Plata". (No hemos podido determinar el año en que tuvo lugar la referida "excursión").

69 Ver: PIVEL DEVOTO, Juan E., De la leyenda negra al culto artiguista., etc., ob. cit., p. 89-91, 146, 157-164.

70 RAMÍREZ, Carlos María, Artigas, Montevideo, Biblioteca Artigas, Colección Clásicos Uruguayos, 1953. La obra era una compilación de los artículos que el autor había publicado ese mismo año en La Razón de Montevideo, en la polémica mantenida con el diario bonaerense Sud América, en respuesta al artículo "La apoteosis de un bandolero" -en el que se criticaba la decisión adoptada por el Presidente Máximo Santos en 1883, de erigir un monumento a Artigas en Montevideo- aparecido en forma anónima en este último órgano de prensa. Clemente Fregeiro atribuyó la autoría de los artículos del Sud América a Lucio Vicente López. Ver: SANSÓN CORBO, Tomás, El espacio historiográfico rioplatense y sus dinámicas (Siglo XIX), La Plata, Instituto Cultural de la Provincia de Buenos Aires, 2011, pp. 133-144. 
Zeballos sobre la existencia una "Memoria Reservada" escrita en 1893 por el entonces senador Carlos María Ramírez sobre el tema de la jurisdicción del Río de la Plata. La "Memoria" había sido elaborada a raíz de la consulta realizada por el Poder Ejecutivo al parlamento, con motivo de la comunicación formulada por el gobierno argentino en relación con la canalización honda del llamado "Canal del Infierno", y había sido leída por su autor en una sesión secreta de la Cámara alta. Relatando dichos antecedentes, Guesalaga decía al canciller argentino:

“...el Dr. Carlos $\mathrm{M}^{\mathrm{a}}$ Ramírez que acababa de crear y de levantar la figura del General Artigas, después de extensas polémicas con un órgano argentino, resolvió hacerle obstrucción al pensamiento llano y sencillo de ejecutar el Canal de Martín García. Tengo datos fidedignos que me aseguran, que el Dr. C. M. Ramírez fue un obstáculo para la ejecución inmediata de esta obra [aconsejando] que no acordasen el consentimiento para el dragaje del Canal sin antes asegurarse de los derechos a la jurisdicción respectiva, mediante la firma de un Protocolo con el Gobierno Argentino que así lo estableciera. ${ }^{71}$

Al tomar conocimiento de la existencia de la "Memoria”, Zeballos ordenó a Guesalaga que hiciera todo lo que estaba a su alcance para conseguirla, esfuerzos que resultaron infructuosos..$^{72}$ Hay que mencionar, asimismo, que el órgano bonaerense Sarmiento muy próximo a Zeballos- también recordaría con rencor a Carlos María Ramírez, en oportunidad de la designación de su hermano como representante uruguayo en la Argentina:

“...El Doctor Gonzalo Ramírez no es, no puede ser persona grata al gobierno y pueblo argentino, por una razón suprema [...] porque pertenece a la familia de los Ramírez. [...]. El doctor Carlos María Ramírez [...] habilísimo periodista en su día, fue el que mas contribuyó a mantener viva e inextinguible la llama de viejos odios entre la patria grande y patria chica que dijera Juan Carlos Gómez. Los estudiantes uruguayos inspirados en sus ideas, en las ideas del autor de la historia del montonero Artigas, negáronse en 1889, a concurrir al puerto de Montevideo a objeto de saludar al general Mitre que venía de Europa $[\ldots]]^{73}$

71Guesalaga a Zeballos, Montevideo, 7 de agosto de 1907. AMREC, DILYF, C.3, c.43, fs. 24-52.

72 Una copia del texto de la "Memoria" de Carlos María Ramírez se encuentra en el Archivo Juan E. Pivel Devoto (UY-AGN), C.155, c.6.

73Sarmiento, Buenos Aires, 30 de julio de 1908: "El nuevo Ministro oriental en Buenos Aires. No es persona grata”. AMREC, DILYF, C.4, Album de Recortes, fs. 5354 . 
Eduardo Acevedo Díaz (1851-1921), político, escritor y publicista, era Ministro uruguayo en Buenos Aires cuando se inicia el conflicto. Perteneciente al Partido Nacional, había sido uno de los ocho diputados de esa colectividad política que habían votado por José Batlle y Ordóñez el $1^{\circ}$ de marzo de 1903, lo que les costó la expulsión de su partido. Batlle había retribuido su apoyo designándolo Ministro del Uruguay en Washington, destino desde el que fue transferido a Buenos Aires. En 1876 había salido en defensa de Artigas, en un artículopublicando en El Siglode Montevideo. ${ }^{74}$ Sus novelas históricas formaron parte de este esfuerzo de construcción de un relato de los orígenes; las más destacadas de esa línea temática ya habían sido publicadas cuando se suscitó el conflicto limítrofe (Ismael, 1889; Nativa, 1890; Grito de Gloria, 1893).

En esta enumeración debemos incluir también a Eduardo Acevedo Vásquez (1857-1948), abogado, periodista (había sido redactor de El Siglo, La Razón y El Tiempo de Montevideo), docente de la Facultad de Derecho, Rector de la Universidad (1904-1906) e historiador. ${ }^{75}$ Sus lazos familiares eran más que significativos: José Pedro Varela, el reformador de la escuela uruguaya (herramienta clave en la construcción de la nación) había sido su cuñado; era primo del representante uruguayo en Buenos Aires, Eduardo Acevedo Díaz, y tío del canciller Jacobo Varela Acevedo. Estas últimas circunstancias lo hacían altamente sospechoso para el Ministro Guesalaga, quien lo consideraba instigador de las posturas intransigentes de su joven sobrino, no olvidando que en su labor periodística "se distinguió casi siempre por sus artículos en contra de los intereses argentinos (no obstante ser de origen argentino)". ${ }^{76}$ Mientras se desarrollaba el conflicto Eduardo Acevedo preparaba la primera edición de su famoso Alegato Histórico(1909) reivindicando la figura de José Artigas, obra que sería reeditada al año siguiente. ${ }^{77}$

Como es sabido, un instrumento clave en la afirmación del sentimiento nacional, es la promoción de las conmemoraciones patrióticas. Por ello es oportuno 74 Ver: PIVEL DEVOTO, J. E., De la leyenda negra al culto artiguista, etc., ob. cit., p. 146-149.

75 Una evaluación de su labor historiográfica en: REAL DE AZÚA, Carlos, "El Uruguay como reflexión (II)", Capítulo Oriental $N^{o} 37$, Montevideo, Centro Editor de A. Latina, 1969, pp.578-579.

76Guesalaga a Zeballos, Montevideo, 3 de noviembre de 1907.AMREC, DILYF, C. 4. c. 17 (I), fs. 648654 .

77 Ver: ISLAS, Ariadna, "Historias, visiones, versiones con motivo de una conmemoración", MUSEO HISTÓRICO NACIONAL, Un simple ciudadano, José Artigas, Montevideo, 2014, pp. 20-21. 
recordar -siguiendo a Carlos Demasi- cómo en el marco del conflicto el diputado del Partido Colorado José María Sosa planteó la necesidad de realizar una conmemoración específicamente "uruguaya" para los festejos del Centenario, demostrando una clara intención de separarse de los festejos que se preparaban en Argentina para Mayo de 1910. Sosa proponía concentrar aquella celebración en el Centenario de la Batalla de Las Piedras, primera victoria obtenida por las fuerzas patriotas, el 18 de mayo de 1811, al tiempo que urgía la concreción del monumento a Artigas en la Plaza Independencia. ${ }^{78}$

La retórica de la confraternidad. No era tan simple, apuntábamos en la Introducción, construir al "otro" tratándose de uruguayos y argentinos. A pesar de las dificultades reiteradas en las relaciones bilaterales los lazos entre ambas sociedades seguían siendo poderosos y eso queda en evidencia en muchos casos. Veamos algunos ejemplos. Al conocerse el texto de la respuesta argentina ante la reclamación uruguaya, los responsables del diario batllistaEl Día expresaron la reacción que el mismo les generaba en estos términos: "Escribimos bajo la dolorosa impresión de una gran decepción”, comenzaba diciendo el autor del artículo, que continuaba así:

\footnotetext{
"La impresión, repetimos, ha sido dolorosa, porque no se podía esperar que el pueblo que tan exactamente hemos llamado amigo y hermano pudiera desconocernos el más indiscutible de nuestros derechos. [...] la tradición fraternal de casi un siglo era un obstáculo formidable para que pudiera plantearse un pleito en condiciones desagradables [pero] nos hemos equivocado; hemos vivido con la convicción de que jamás tendríamos un rival en el vecino del otro lado del Plata; hemos sido bastante cándidos para creer en afectos que no existían y bastante sinceros para experimentarlos sin que se nos correspondiera".
}

En la nota no faltó la alusión a la paradoja que encerraba esta situación de conflicto entre ambas naciones cuando se avecinaban las conmemoraciones del Centenario: "Toda la tradición de fraternidad, todos los lazos históricos que nos unen a la república vecina [...] parecen derrumbarse precisamente en el momento de aproximarse el centenario de la revolución de Mayo". ${ }^{79} \mathrm{Pocos}$ días después, en el mismo diario y en un artículo sin firma - pero cuya autoría el Ministro Guesalaga

78 Ver: DEMASI, Carlos: “La construcción de un 'héroe máximo’: José Artigas en las conmemoraciones uruguayas de 1911”, Revista Iberoamericana, Vol. LXXI, Núm. 213, Octubre-Diciembre 2005, p. 1035.

79El Día, Montevideo, 3 de noviembre de 1907: "La cuestión internacional. Ayer y hoy". 
atribuía a Samuel Blixen- se criticaba nuevamente la gestión de Zeballos, calificándola de torpe, porque había sido capaz de "romper la única amistad sincera y leal con que podía contar en el exterior la patria de Sarmiento". Hasta un mes atrás, señalaba el articulista,

“...contábamos con los argentinos como ellos contaban con nosotros. [...] Nos considerábamos todos unos, y era tal la solidaridad creada por el común origen político y por varios lustros de amistad no interrumpida, que al comenzar el conflicto, se engañó sobre su alcance el instinto de la muchedumbre y nadie le otorgó importancia. [...] Pero el canciller argentino no ha querido que las cosas pasaran tan sencillamente, y con tal acierto o tal torpeza ha conducido sus gestiones, que ha enajenado a su país, y quizás irremediablemente, las simpatías del pueblo uruguayo". ${ }^{80}$

En la misma línea podemos ubicar la postura del órgano montevideano $E l$ Siglo -dirigido por Juan Andrés Ramírez, hijo de Gonzalo Ramírez- que inició la extensa cobertura sobre la firma del Protocolo Ramírez-Sáenz Peña el 5 de enero de 1910 con este párrafo: "El pueblo oriental ha salido ayer de la terrible violencia moral que significaba para él, no ver en el argentino el fraternal amigo de todos los tiempos" ${ }^{81}$

Desde Argentina, es preciso señalar, no todos vieron a los uruguayos de la misma forma con que lo hicieron el canciller Zeballos y el Ministro Guesalaga. También hubo quienes llamaron a moderar los planteos y a preservar los lazos de amistad fraternal. Entre ellos, y a manera de cierre de este avance de investigación, transcribimos este penetrante comentario escrito por Ramón J. Cárcano, en carta enviada al Presidente Figueroa Alcorta en enero de 1909:

"Estos días he hablado con mucha gente principal, empezando por S. E. [Williman]. [...] Hay verdadero interés por concluir con todo rozamiento con nosotros, y en este sentido los espíritus son optimistas. Las vinculaciones de raza, de historia, idioma, intereses, sociabilidad y vecindad, no las conmoverá nadie seriamente. Es la obra del origen común acentuada por siglos de contacto permanente, y la concordia que cualquiera puede resentir con mucho trabajo, cualquiera otro que venga la restablecerá con mucha facilidad. Cada vez que estudio y penetro más los hombres y espíritus de este país me

80El Día, Montevideo, 12 de noviembre de 1907: "Charlas de un montevideano". 81El Siglo, Montevideo, 6 de enero de 1910: "El gran triunfo de la justicia internacional. La cuestión del Plata resuelta”. 
persuado más que no tenemos mejores amigos. Pero hay que cuidar y cultivar con buena fe estos sentimientos, por que la debilidad es muy susceptible". ${ }^{82}$

\section{Reflexiones finales}

No obstante lo acotado -en varios sentidos- del presente acercamiento, podemos aventurar algunas conclusiones primarias. El conflicto que enfrentó a Uruguay y Argentina por los límites del Río de la Plata a comienzos del siglo XX no solo ocupó y preocupó a los elencos gubernamentales de los dos países, sino que generó reacciones en sectores más amplios de la sociedad. A ello contribuyó el papel jugado por la prensa periódica en ambos países, embarcada en la defensa de lo que sus redactores consideraban los derechos jurisdiccionales de su país, pero también actuando muchas veces como instrumentos de las estrategias propagandísticas de lascancillerías respectivas.

El enfoque elegido en este abordaje, que optó por no limitar el trabajo a un análisis anclado exclusivamente en las negociaciones diplomáticas, permite apreciar cómo la disputa limítrofe hizo aflorar imágenes y provocó reacciones que muestran el creciente afianzamiento del sentimiento de identidad nacional. También muestra, más allá del enfrentamiento coyuntural, la existencia de sólidos vínculos de todo tipo entre las sociedades que el Río de la Plata separa (¿une?). Para decirlo con las palabras de Ramón J. Cárcano que citábamos más arriba, "la concordia que cualquiera puede resentir con mucho trabajo, cualquiera otro que venga la restablecerá con mucha facilidad". Una afirmación que podríamos suscribir hoy, pero esa es otra historia.

\section{Bibliografía}

ACEVEDO, Eduardo. Anales históricos del Uruguay. Tomo V, Montevideo, Barreiro y Ramos, 1934.

AROCENA OLIVERA, Enrique. Evolución y apogeo de la diplomacia uruguaya. 1828-1948. Montevideo, Imp. Palacio Legislativo, 1984.

82 R. J. Cárcano a J. Figueroa Alcorta, Montevideo, 24 de enero de 1909. (AGNA-AFA), Legajo 19. 
BARRAN, José Pedro y NAHUM, Benjamín. Batlle, los estancieros y el imperio británico.Tomo 2: Un diálogo difícil, y Tomo 6: Crisis y radicalización (19131916), Montevideo, Ediciones de la Banda Oriental, 1981 y 1985.

BERTONI, Lilia Ana, Patriotas, cosmopolitas y nacionalistas: la construcción de la nacionalidad argentina a fines del siglo XIX. Buenos Aires, FCE, 2001.

BUENO, Clodoaldo. "O rearmamento naval brasileiro e a rivalidade Brasil-Argentina em 1906-1908”, Historia, v. 1, pp. 21-35, Sao Paulo, 1982.

CAVALERI, Pablo. La restauración del Virreinato. Orígenes del nacionalismo territorial argentino. Buenos Aires, Universidad Nacional de Quilmas, 2004.

CUADERNOS DE MARCHA No 20, El Río de la Plata. Montevideo, diciembre 1968.

DE LOS SANTOS FLORES, Clarel. Soberanía e identidad nacional en el Uruguay del novecientos. Incidencias regionales y nacionales en la gestación del Tratado de Rectificación de Límites entre Uruguay y Brasil en 1909. Montevideo, UdelaR, FHCE, 2010. (http://www.fhuce.edu.uy)

DEMASI, Carlos. "La construcción de un 'héroe máximo': José Artigas en las conmemoraciones uruguayas de 1911”, Revista Iberoamericana, Vol. LXXI, Núm. 213, Octubre-Diciembre 2005, pp.1029-1045.

DEMASI, Carlos. La lucha por el pasado: historia y nación en Uruguay (19201930). Montevideo, Ediciones Trilce, 2004.

DIAZ DE MOLINA, Alfredo. José Figueroa Alcorta. De la oligarquía a la democracia. 1898-1928. Buenos Aires, Editorial Plus Ultra, 1979.

DORATIOTO, Francisco. O Brasil no Rio da Prata (1822-1994). $2^{\text {a }}$ ed., Brasilia, FUNAG, 2014.

ESCUDÉ, Carlos y CISNEROS, Andrés. Historia General de las Relaciones Exteriores Argentinas. Edición digital disponible en la página web: http://www.argentina-rree.com/historia.htm

ETCHEPAREBORDA, Roberto. Zeballos y la política exterior argentina. Buenos Aires, Pleamar, 1982.

FERNÁNDEZ, Sandra y NAVARRO, Fernando (Coordinadores). Scribereestagere. Estanislao Zeballos en la vorágine de la modernidad argentina. La Quinta Pata\& Camino Ediciones, Rosario, Argentina, 2011. 
FERRARI, Gustavo. Estanislao S. Zeballos. Consejo Argentino para las Relaciones Internacionales. Colección "Los Diplomáticos". s/f.

FREGA, Ana. "La construcción monumental de un héroe”, Humanas 18/1-2. Porto Alegre, 1995, pp. 121-149. (el artículo fue reeditado, con el mismo título, en MUSEO HISTÓRICO NACIONAL. Un simple ciudadano, José Artigas. (Catálogo de la exposición del mismo nombre). Montevideo, 2014.

GARCÍA MOYANO, Guillermo. "Pueblo de los Pocitos", en: Josefina Lerena Acevedo, Arturo Jiménez Pastor, Guillermo García Moyano y Rafael Sienra, Memorias del Novecientos, Montevideo, Ed. Banda Oriental, 2007.

IRIYE, Akira (editor). Mutual images. Essays in American-Japanese Relations. Harvard University Press, 1975.

ISLAS, Ariadna. "Límites para un Estado. Notas controversiales sobre las lecturas nacionalistas de la Convención Preliminar de Paz de 1828”, Ana Frega (coord.), Historia regional e independencia del Uruguay. Proceso histórico y revisión crítica de sus relatos. Montevideo, Ed. Banda Oriental, 2009, pp. 169216.

LACOSTE, Pablo y ARPINI, Adriana."Estanislao Zeballos, la política exterior argentina, la ideología racista de la elite ilustrada rioplatense y la reforma universitaria de 1918”, Revista UNIVERSUM, No 17, Universidad de Talca (Chile), 2002, pp. 125-146.

LACOSTE, Pablo. “Chile y Argentina al borde la guerra (1881-1902)”, en Anuario del $C E H, \mathrm{~N}^{\circ} 1$, Año ${ }^{\circ}$, Córdoba, 2001, pp. 301-328.

LACOSTE, Pablo. "Estanislao Zeballos y la política exterior Argentina con Brasil y Chile”, en: Revista Confluencia, año 1, número 2, primavera 2003, Mendoza, Argentina, pp. 107-128.

LOIS, Carla. “Técnica, política y 'deseo territorial' en la cartografía oficial de la Argentina (1852-1941)”, Scripta Nova. Revista electrónica de Geografía y Ciencias Sociales., Universidad de Barcelona, Vol. X, nú. 218 (52), agosto 2006.http://www.ub.edu/geocrit/sn/sn-218-52.htm. [Consulta: 11 de noviembre 2015].

MUSEO HISTÓRICO NACIONAL. Un simple ciudadano, José Artigas. Montevideo, 2014. 
NAHUM, Benjamín. Informes diplomáticos de los Representantes del Reino Unido en el Uruguay. Tomo I. 1903-1911. Montevideo., Ministerio de Educación y Cultura, 1991.

PIVEL DEVOTO, Juan E. De la leyenda negra al culto artiguista.[1950-1951] Montevideo, Biblioteca Artigas, Colección de Clásicos Uruguayos, Volumen 171,2004

PIVEL DEVOTO, Juan E. Historia de los límites del Río de la Plata. Islas Martín García y Timoteo Domínguez. Montevideo, Cámara de Senadores, 1973.

RODRÍGUEZ

AYÇAGUER,

Ana

María.

"Elpreciodelapaz.Ladiplomaciaargentinaylautilizacióndela 'amenaza'

delaguerracivilparapresionaralgobiernodeClaudio

WillimanduranteelconflictoporlajurisdiccióndelRíodelaPlata(1907-

1910)”.Ponencia.IVJornadasdeHistoriaPolítica, FCS,Montevideo, julio2013.

SANSÓN CORBO, Tomás. El espacio historiográfico rioplatense y sus dinámicas

(Siglo XIX). La Plata, Instituto Cultural de la Provincia de Buenos Aires, 2011.

SIEGRIST de GENTILE, Nora L. "Política exterior argentina durante la Presidencia

Figueroa Alcorta (1906-1910).El Memorandum Secreto del Doctor Estanislao S.Zeballos", SIEGRIST de GENTILE, Nora L., GIRBAL DE BLACHA, Noemí y BRAILOVSKY, Antonio Elio. Tres estudios argentinos. Buenos Aires, Editorial Sudamericana, 1982.

TURCATTI, Dante. El equilibrio difícil. La política internacional del Batllismo. Montevideo, Ed. ARCA-CLAEH, 1981.

VANGER, Milton. El país modelo. José Batlle y Ordóñez. 1907-1915. Montevideo, Editoriales ARCA y Banda Oriental, 1983.

WILliman, Arq. José Claudio. El Dr. Claudio Williman. Su vida pública. Montevideo, Talleres Gráficos "Prometeo", 1957.

ZEBALLOS, Estanislao S. Diplomacia desarmada. Buenos Aires, EUDEBA, 1974.

\section{Fuentes inéditas}

ARCHIVO DEL MINISTERIO DE RELACIONES EXTERIORES DE ARGENTINA, Buenos Aires. Dirección Límites y fronteras (AMREC-DILYF), Cajas 3 y 4. 
ARCHIVO HISTÓRICO DIPLOMÁTICO DEL MINISTERIO DE RELACIONES EXTERIORES DE URUGUAY, Montevideo(AMREU.Fondo Ministerio de Relaciones Exteriores, Sección Misiones Especiales Varias, Mueble 4, Caja 1, Sobre 4: "Correspondencia epistolar mantenida entre Eduardo Acevedo Díaz y Jacobo Varela Acevedo (Ministro de RR.EE.). Jurisdicción de aguas del Plata. Año 1907".

ARCHIVO GENERAL DE LA NACIÓN ARGENTINA, Buenos Aires.Archivo del Dr. José Figueroa Alcorta. (AGNA-AFA), Legajos 15 y 19.

ARCHIVO GENERAL DE LA NACIÓN de Uruguay, Montevideo. Archivo Histórico,Colecciones y Archivos Privados:

-Archivo del Dr. Claudio Williman (UY-AGN, AW): Cajas 285 a 288 y 305 a 315 .

-Archivo de Juan E. Pivel Devoto (UY-AGN, APD), Cajas 41, 47, 115, 126, 130, 139, 140, 155, 159 a 163, 167 a 169, 173, 175, 177 y 181.

MUSEO HISTÓRICO NACIONAL, Uruguay.Archivo de Antonio Bachini (MHN-AB) Carpetas 1646 a 1653. 